(a)

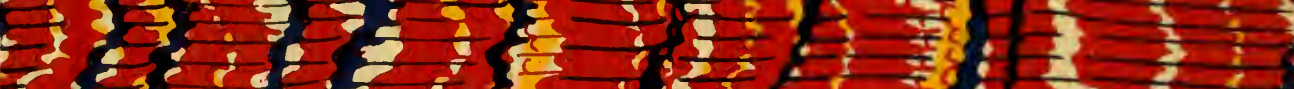

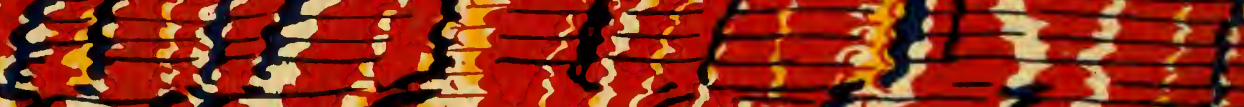

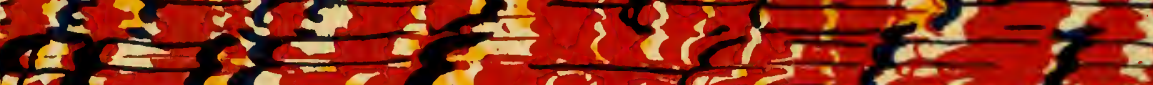

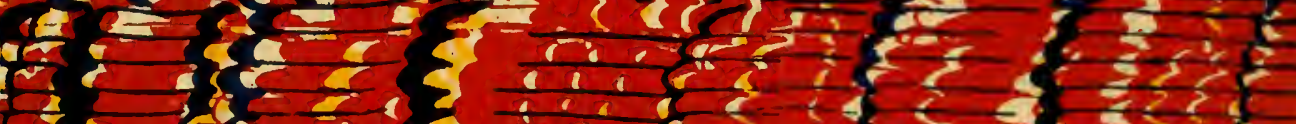

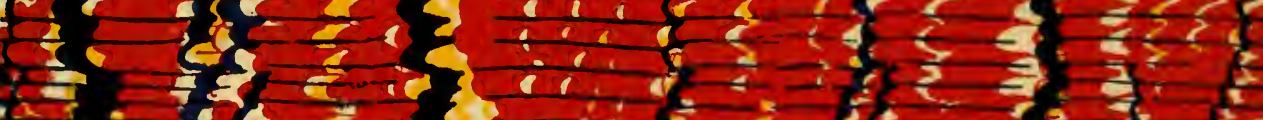

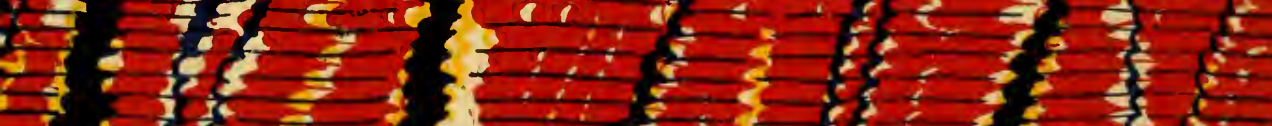

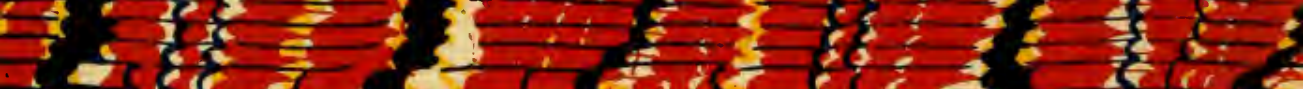

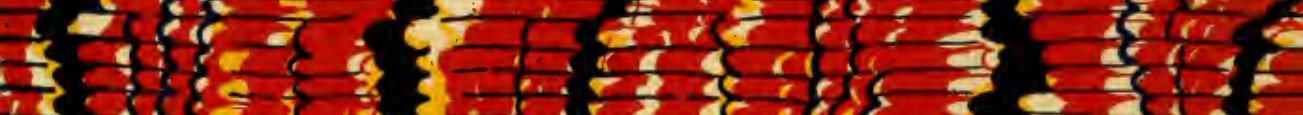

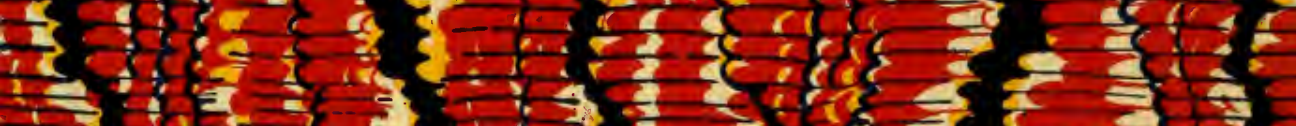

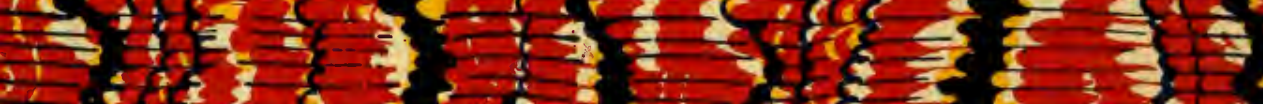
की ती

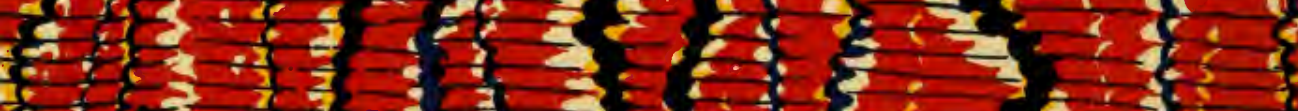

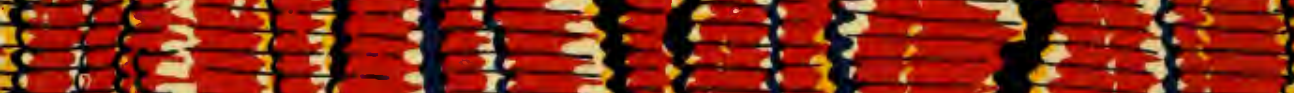

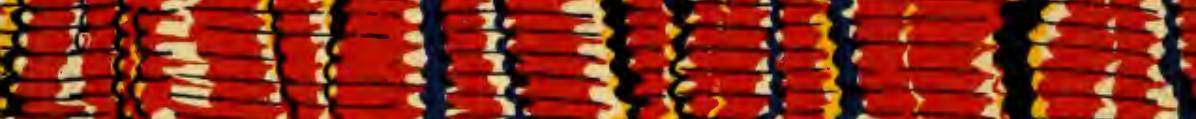

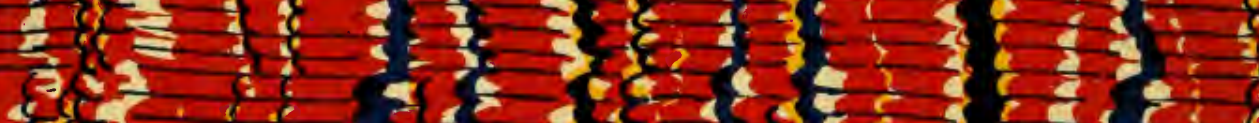

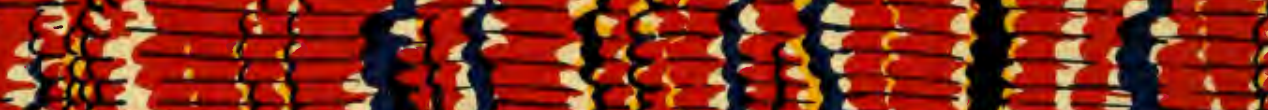

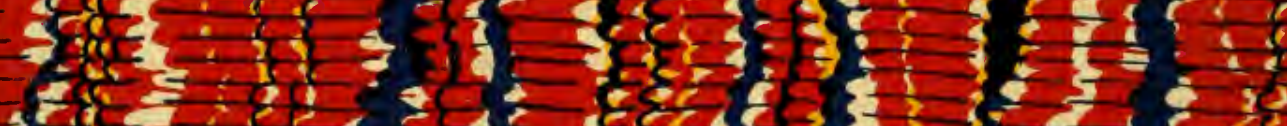
a

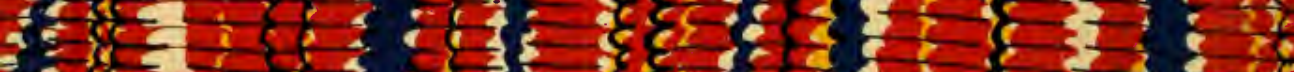

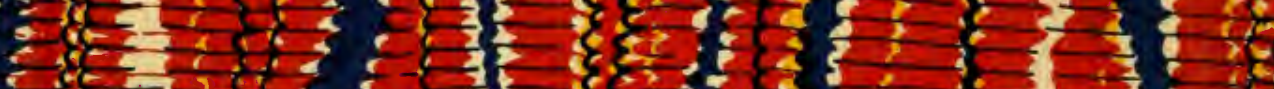

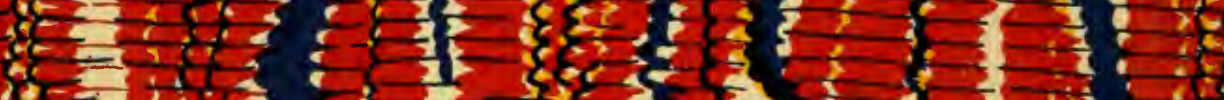

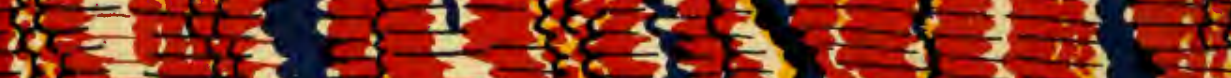

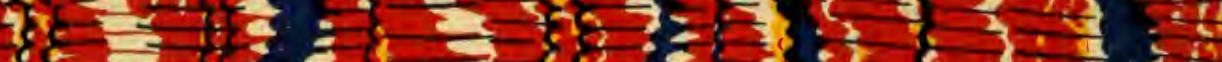

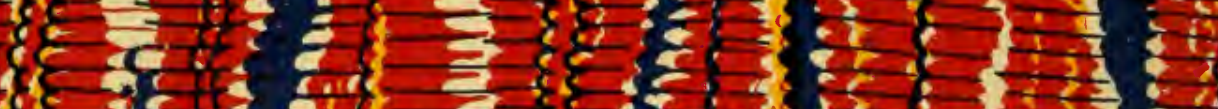

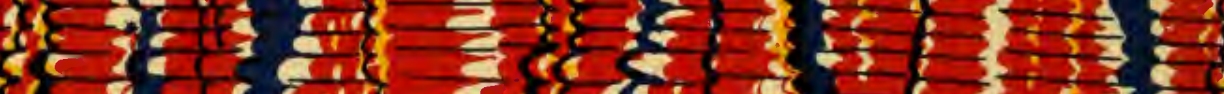

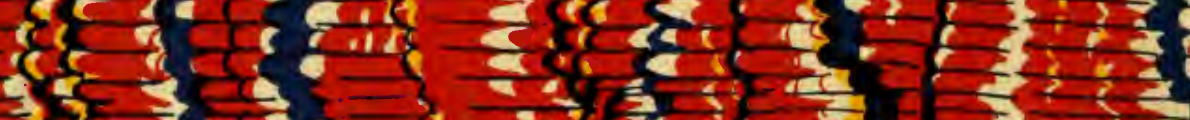

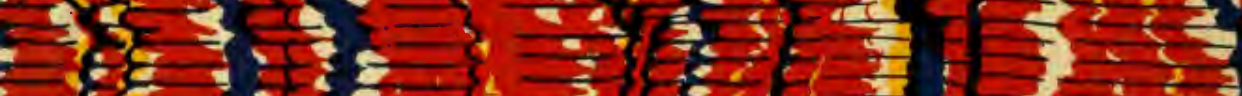

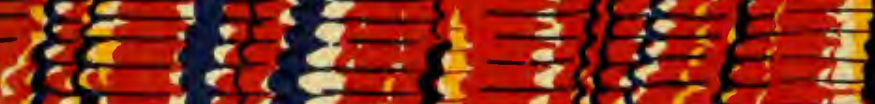

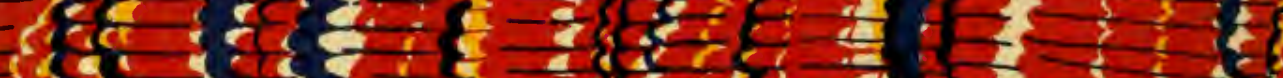

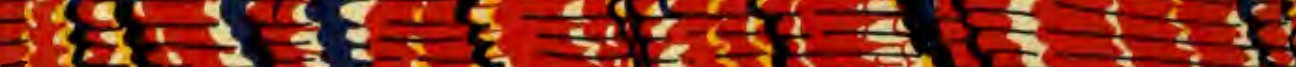

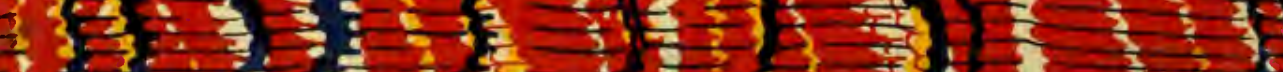

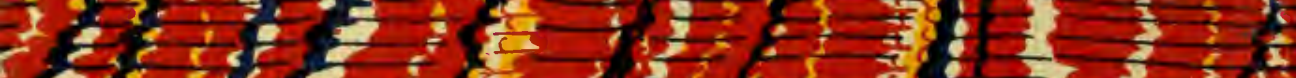

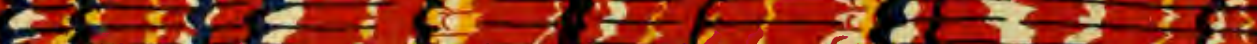




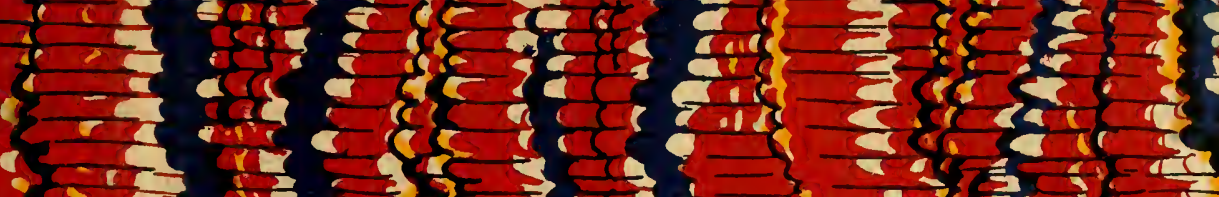

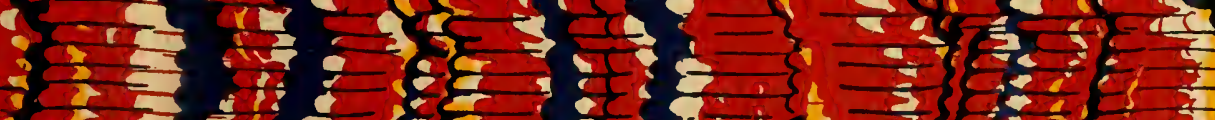

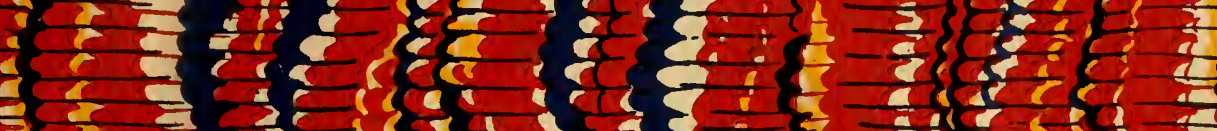

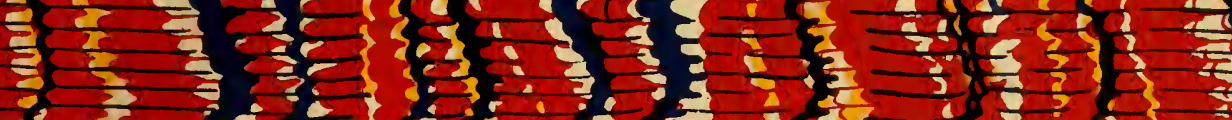

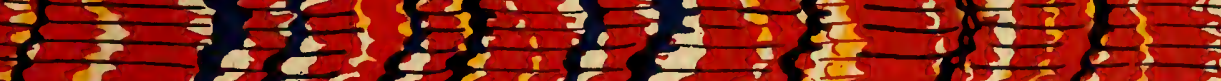

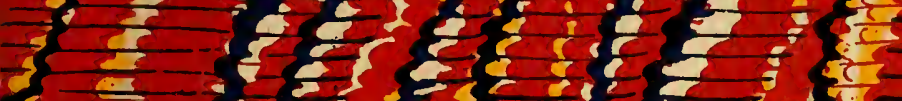

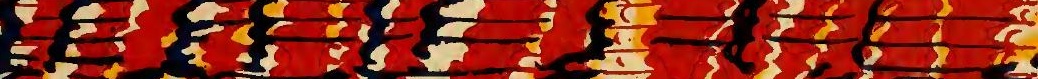

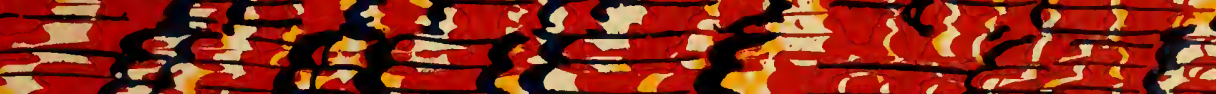

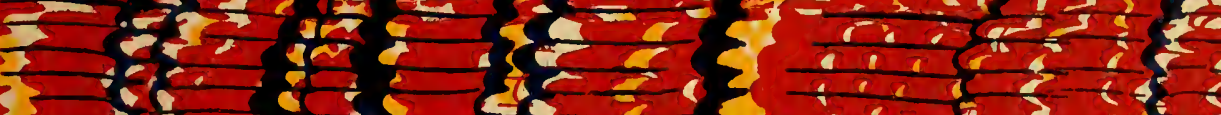

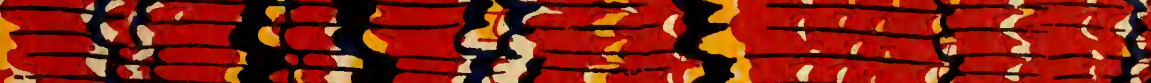

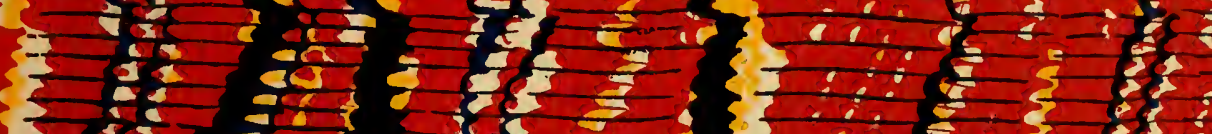

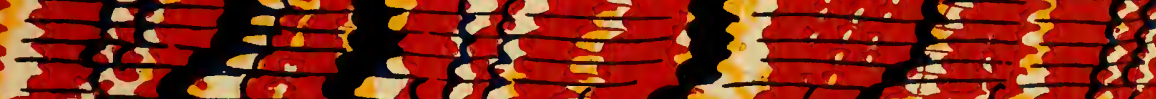

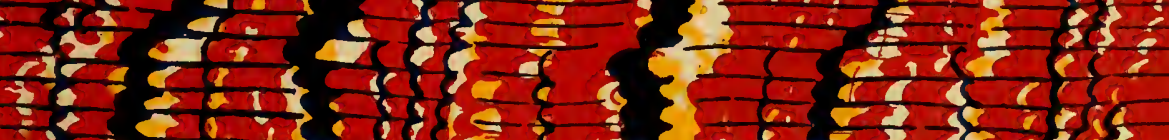

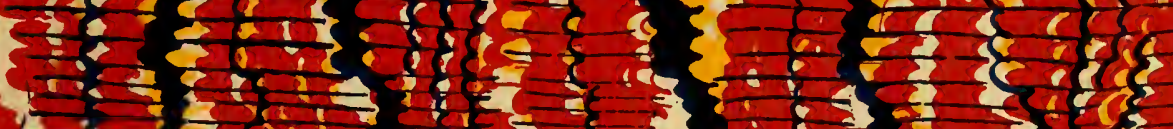

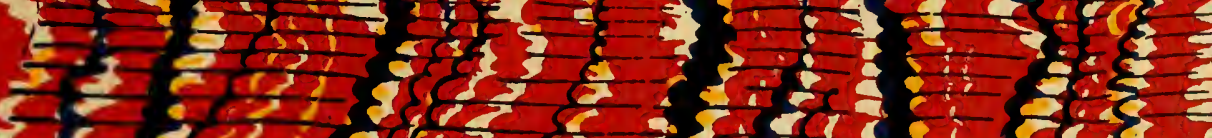

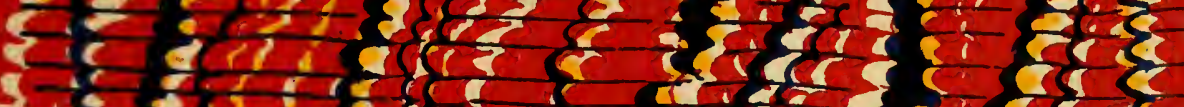
I.

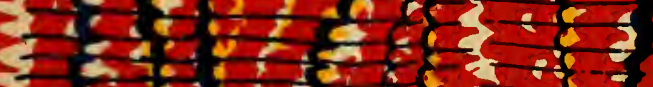

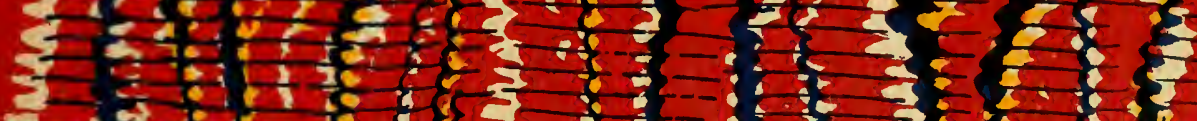

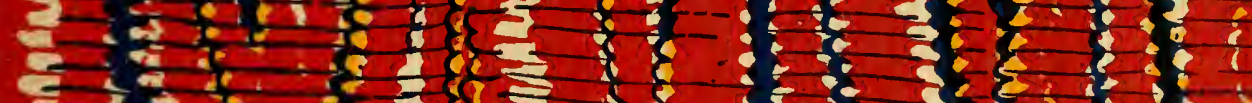

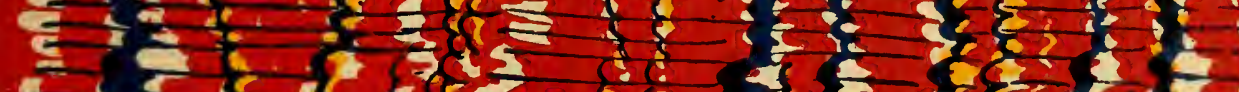

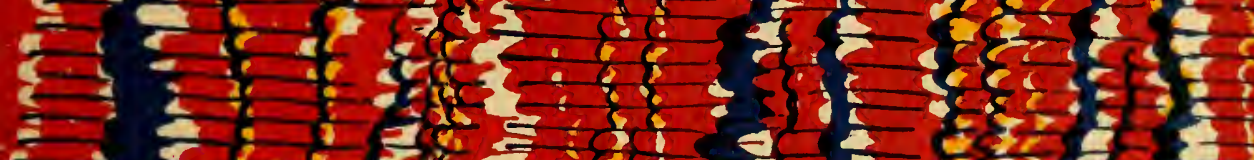

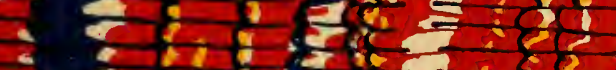
a

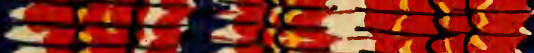

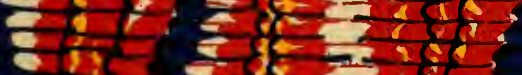

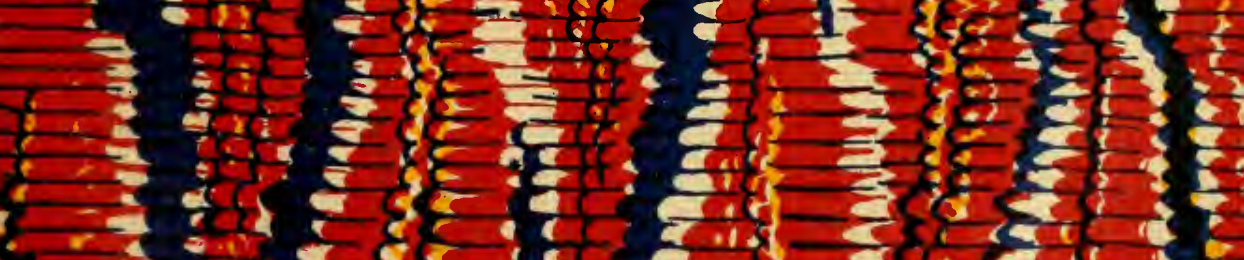

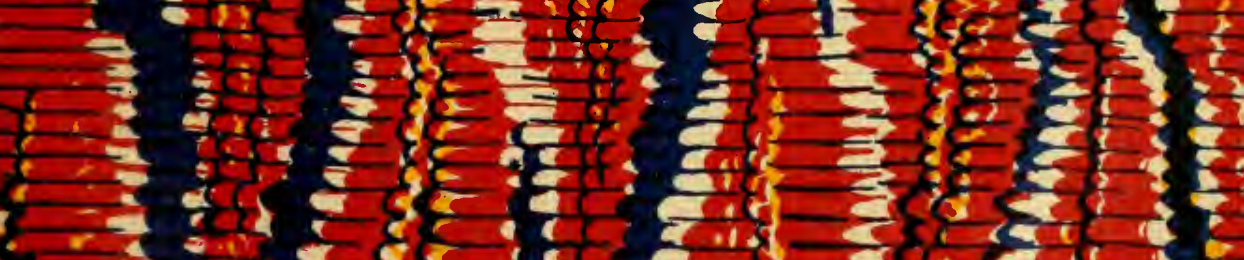

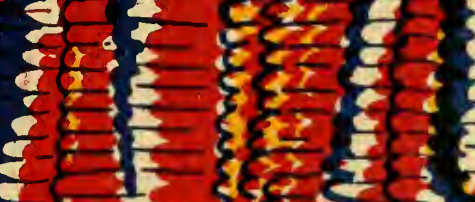

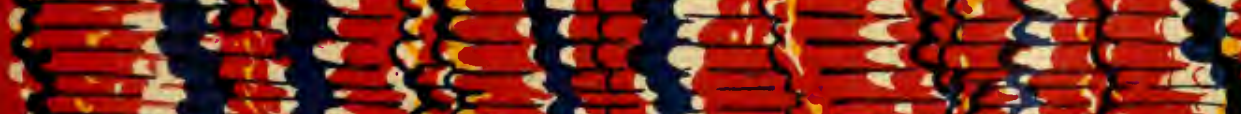

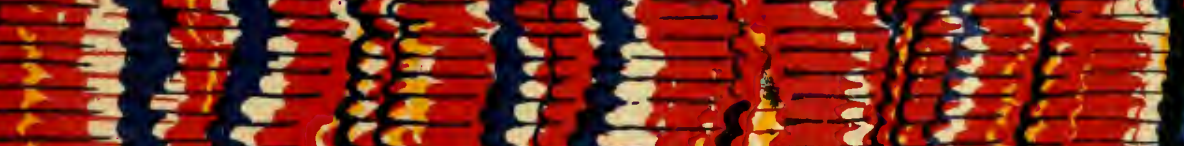

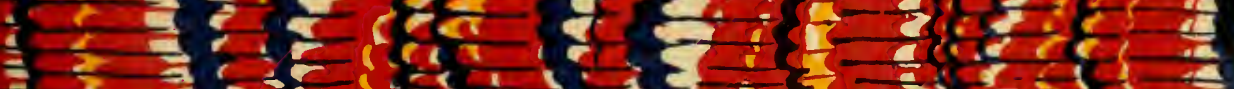

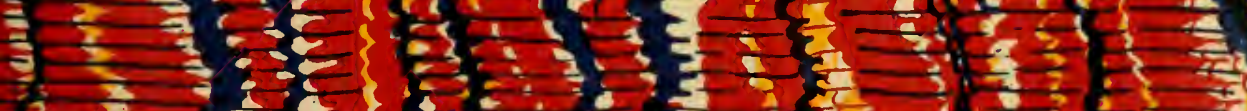

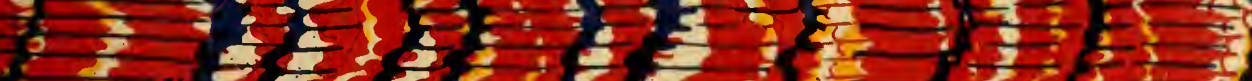






QL

653

M4.588

18.39

REPT

$$
\text { Sil-orer, Daud tumphreys }
$$

\section{REPTILES OF MASSACHUSETTS.}





\section{To George B. Exierson, Esq.}

\section{My Dear Sir :}

Most reluctantly do I offer you the accompanying Report upon the Reptiles of Massachusetts. IIaving devoted the greater part of the leisure time I could claim, since the commencement of my duties as a Zoological Commissioner, to an investigation of our Fishes, as being the more extended and far more important branch, I have, without neglecting any opportunity which could be presented by friends and correspondents, been unable to give our reptiles that careful attention and study, which can alone satisfy the searcher after facts. Descriptions of every species of reptile of which $I$ have any knowledge in the State, having however been prepared as they were received, although with very different degrees of diffuseness, I now collect together and present them, conscious that, knowing the untoward circumstances under which I have labored, my scientific friends, at least, will overlook many imperfections.

The catalogue of our reptiles contained in Professor Hitchcock's Survey, prepared by Dr. Smith, of Sutton, contains most of our species, and was evidently drawn up with care; but as he has given no descriptions by which we may judge of his accuracy, I have felt at liberty, when a species has been catalogued which clearly should not be, or which the best herpetologists in our country, well acquainted with the reptiles of New England, have never seen in our latitude, to omit it.

Thus we find catalogued the "Testudo scabra." This error may have been produced by Say's incorrectly including this species in a paper "On the fresh watcr and land Tortoises of the Unitcd Statcs," published in the fourth volume of the Journal of the Academy of Natu$r$ al Sciences. The species he considered the "scabra," is the "insculpta."

The "Testudo Pennsylvanica" is plainly confounded with the "Sternothaerus odoratus," a widely-distributed species.

The "Coluber striatulus" of that catalogue, I have also omitted; not merely because I liave not met with it myself, but because my friend Dr. Pickering, an accomplished naturalist, thoroughly versed in the herpetology of New England, assures me, he not only never met with it here, but never heard of its having been found here, it being strictly a southern species. 
The "Rana clamata" I have also erased, because no one of my scientific friends has ever met with it; and Dr. Holbrook, who well knows the species, and has visited this portion of the country repeatedly of late years, to collect materials for his great work, says, in his third volume, this species " is found in the low countries of Carolina and Georgia; farther north than this, I have never seen it."

"The "Salamandra cinerea" is onitted, because Dr. Green, who first described it, as well as the "erythronota," considers them both one species.

The "Salamandratigrina" and "longicauda" may perhaps both be found here; but knowing no one who had ever seen them in this State, I wrote to Dr. Emmons, upon whose authority they were given in that catalogue, for information; he writes me, that he thinks he has seen a specimen of each, but adds: "I will not take the responsibility of giving these two species as citizens of the Bay State. I have not studied them carefully enough to be authority."

Ilaving erased the above mentioned species, and introduced three Tortoiscs, two Colubers, one Heterodon, one Rana, one Hylodes, four Salamanders, and on Scincus, which were not noticed in the catalogue referred to, the Herpetology of our State, as far as I have been able to learn, is composed of fourteen genera and thirty-nine species. More extended investigation will undoubtedly ascertain the existence here of new species, as well as of many which have been already described by naturalists.

Meager though this Report may be considered, friends have kindly tendered their aid in its preparation, and I would express to them my thanks. To the following gentlemen I am particularly indebted:

To Mr. Alonzo Gray, of Andover, for numerous living specimens of Tortoises, Colubers and Salamanders;

To Professor C. B. Adams, of Middlebury College, Vt., for many beautiful living specimens, and much valuable information respecting them;

To Amos Binney, M. D. of Boston, for free access to his rich and very valuable library, at all times, whereby I have been enabled to consult volumes, of which he possessed the only copies in this portion of the country.

Trusting that you will be satisfied that an effort has been made to perform the duty required of me as accurately and faithfully as circumstances would allow, I remain,

Your friend and servant,

\section{HUMPHREYS STORER.}




\title{
REPTILES OF MASSACHUSETTS.
}

\section{O R D E R I.}

\author{
CHELONIA.
}

Exys. Brogniart.

Generic characters. Shell depressed, solid; sternum broad, solid, immoveable, firmly joined to the shell, consisting of twelve plates, and four supplemental ones ; extremities palmated, anterior with five nails, posterior with four; head of ordinary size; tail long.

E. guttata. Schneider.

Shaw's Gen. Zoology, vol. iii. pt. 1. p. 47, et fig.

Ann. Lyc. Nat. Hist. N. Y. vol. iii. p. 117.

Harlan's Med. and Phys. Res. p. 151.

Dum. et Bibron, Hist. Nat. les Rept. tom. ii. p. 295.

N. A. Herp. vol. ii. p. 25, et fig.

This, our most common species of tortoise, is found in small streams and clear water throughout the State, oftentimes in great numbers; a very concise description only is therefore offered:

The upper shell is black, sprinkled over its whole surface with more or less distant, roundish, bright yellow spots. In some specimens, eight or ten quite small spots may be seen crowded upon a single plate; while in others, several of the plates, particularly those on the dorsum, exhibit lut one spot each, brighter colored and larger than those just referred to. 
The sternal plates are yellowish, with large black blotches, or black with yellowish blotches, or uniformly black. Sometimes the plates of the stermum are perfectly smooth, at other times marked with concentric strix. The top of the head, and upper part of the legs, black with yellow spots.

It feeds upon insects, worms and frogs.

E. picta. Schneider. The painted Tortoise.

Shaw's Gen. Zoology, vol. iii. pt. 1. p. 45, et fig.

Ann. Lyc. Nat. Hist. N. Y. vol. iii. p. 115.

Harl. Med. and Phys. Res. p. 151.

Dum. et Bibr. Hist. Nat. des Rept. tom. ii. p. 297.

N. A. Herpet. vol. ii. p. 19, et fig.

Next to the "guttata," this is the most generally distributed species. It is usually found with the preceding, and is a very easily recognised species. A specimen five inches in length, serves for the following description:

Body above, compressed; upper shell, greenish brown, with the edges of the dorsal and lateral plates margined with yellow. A very narrow dorsal yellow line passos from the anterior to the posterior marginal plate; the marginal plates are darker colored than the other plates of the upper shell, having in their centre a bright red blotch, which is much larger upon the inferior side; and over this blotch, one or two red markings, which are concentric upon the plates not attached to the sternum, and nearly straight upon the four plates which are thus attached; the red color predominates upon the under sicle of the marginal plates.

First dorsal plate quadrangular: second and fourth, hexagonal ; third, cuadrangular; fifth, heptagonal.

Stcrnal plates yellow, with a triangular ribbon upon the anterior portion, and a straight one upon the middle and posterior portions, of a brighter tint.

Back of the head, dark brown; directly back of the eyes, a broad yellow band; a narrower band of the same color runs 
also back, from the middle of the eye. From the tip of the snout, a narrow yellow line runs to each eye ; from the side of the mouth also, two lines pass to the middle of the eye, and two from the lower edge of the jaw. From the extremity of the lower jaw, two larger bands run backwards; the first passes slightly down, then outwardly to the angle of the lower jaw, whence it is continued by a broad bright yellow band; within this, from the middle of the lower jaw, a narrower band of the same color passes back parallel with this; and from the tip of the chin a band runs down a short distance, and then bifurcates into broader bands. These yellow lines upon the head become red upon the neck, and are continued on to the shoulders of this color. Two large yellow spots upon the occiput. Eyes small ; pupils, a deep black; irides golden; a dark line running through their centre. Fore leg's black, a red band passing through their centres; and the commencement of a second, on a line with the base of the previous one; phalanges marked with red lines. Hind feet, dark brown, above; beneath, lighter, with a red band on each side. Tail of moderate length, with two narrow Iongitudinal yellow bands uniting at the posterior extremity; beneath, marked by the narrow red lines of the legs continued, which unite at the posterior portion, forming a single red band.

Its food is the same as that of the previous species.

E. insculpta. Le Conte. The wood Tortoise.

Ann. Lyc. N. Y. vol. iii. p. 112.

Harlin's Med. and Phys. Res. p. 152.

Dum. et Bibr. Uist. Nat. des Rept. tom, ii. p. 251.

Specimens of this, our most beautiful tortoise, I have received from Walpole, Concord, Amherst and Andover, and learn that it is not uncommon in the ponds of several other portions of the State. This species wanders a great distance from, and remains a long time out of the water; and being oftentimes found in woods and pastures, has received the com- 
mon name of wood tortoise. Its usual length is from six to eight inches. The uprer shell is composed of five dorsal, eight lateral, and twenty-five marginal plates; these plates are of a greenish brown color, strongly marled with concentric and radiating strix. A dorsal ridge is formed by the convex portion of the superior plates. Sternum composed of twelve yellow plates, having upon their posterior lateral margins, a large black spot. All the under portion of the legs, neck and tail, is red.

Young specimens exhibit a very rough upper shell, produced by the prolongations of the posterior angles of the plates.

This species was erroneously considered by Say, as synonymous with the "scabra," Lin.; and as such, he catalogned it the 4th Vol. J. A. N. S.

\section{Sternothaerus. Bell.}

Generic characters. Head sulquadrangular, pyramidal, covered in front with a single plate; warts on the chin; marginal plates, twenty-three; sternum cruciform, bivalve, anterior valve only moveable; supplemental plates contiguous, placed on the sterno-costal suture; anterior extremity with five nails, posterior with four.

\section{S. odoratus. The mud Tortoise.}

Ann. Lyc. Nat. Hist. N. Y. vol. iii. p. 122.

Ilarl. Mled. and Phys. Res. p. 156.

Dum. et Bibr. Hist. Nat. des Rept. tom. ii. p. 358.

N. $\Lambda$. Herpet. v. iii. p. 29 , et fig.

Shell oblong, convex, somewhat carinated on the dorsal ridge; of a brownish color, irregularly blotched with darker spots.

The first vertebral plate is triangular, the next three hexagonal, the last pentagonal. There are four lateral plates; the first of which is quadrangular, the remainder are pentagonal. The marginal plates, twenty-three in number, are small, gen- 
erally elongated, forming a margin; the posterior plates largest, and appearing as if they were a continuation of the last vertebral plate.

Sternum small, composed of nine yellowish brown plates; it is divided into three portions by two ligamentous hinges; the anterior, composed of three plates, is quite moveable upon the second division; the third portion, of four plates, the posterior of which are emarginated, and have their posterior angles acute, althongh united to the second division of the sternum, consisting of the two large abdominal plates, by a similar hinge with the first, is scarcely moveable.

Head pointed, flattened above ; snout, truncated. Eyes moc'erate in size; pupils black, irides golden. Nostrils large at the extremity of the snout. Top of the head nearly black. A narrow yellow line passes frem the tip of the snout backwards over each eye, and is lost upon the neek; a second line of the same color, larger and much brighter, is continned backward beneath the eyes to the neck. A broad yellow band is also observed upon each side of the chin, exhibiting a striking contrast with the dark brown color of the jaws. Skin of the neck, throat and legs, ash eolored. Neck, covered with granulations. Several yellowish warts or cirrhi upon the throat. Legs and feet slightly granulated; upon the anterior legs, three large scaly plates; at the base of the feet several smaller scales of a similar character; these scales do not exist upon the legs of the posterior extremities, although they do upon the feet. 'Toes palmated; fore feet with five toes, and five claws; rosterior, five toed, with four claws. Tail short, with several rows of pointed warts.

The spccimen from which I have drawn the above description, is three inches and a half long, one inch and a half high. Of six specimens lying before me, five do not vary a line in length. The sixth, which is considerably younger, is less than three inches in length; has a more marked dorsal ridge than either of the others, and the blotches are more numerous. 
This species has a very disgusting odor, and is hence sometimes called stink-pot.

It is found burying itself in the mud in ditches and small ponds, frequently covered with a thick coat of foreign matter, from which circumstance it has received the common name of mud tortoise.

A single specimen of this species was found in Fresh Pond in Cambridge by J. W. Randall, M. D. ; one specimen was taken at Amherst, and several at Falmonth by Professor C. B. Adams; and Mr. Erastus $\mathbf{H}$. Clap has brought me one from Walpole.

\section{Emysaurus. Dumeril.}

Generic characters. Head large, covered with small plates; snout short; jaws hooked; two warts beneath the clin; sternum immovcable, cruciform, composed of ten plates; three sterno-costal plates; fore feet with five claws, hind feet with four; tail long, surmounted with a scaly crest.

E. serpentina. Lin. The snake Tortoise.

Shaw's Zoology, vol. iii. pt. 1. p. 72, et fig.

Ann. Lyc. N. Y. vol. iii. p. 128.

Dum. et Bibr. Hist. Nat. des Rept. vol. ii. p. 350.

This is the largest tortoise found within the borders of our State; sometimes weighing from 15 to 20 pounds. It is exceedingly powerful and voracious, feeding upon fishes and frogs; and the farmers sometimes complain of. its depredations among their chickens and ducklings. From its liabit of snapping suddenly at almost every thing offered it, it is generally known by the name of the "snapping tortoise," in New England, while its crested tail, resembling the Crocodilus lucius, gives it the distinction at the South, of "alligator tortoisc." It is usually found in filthy water, and is occasionally met with at considerable distance from any pond or pool, dragging itself leisurely along. 
The flesh of this species is often used as food, and when made into a soup is considered by many as quite a delicacy. The oil obtained from this species is carefully preserved in many portions of the interior of the State, for its supposed virtues in bruises, sprains, \&c. when externally applied.

The upper shell is of a dark brown color, oval, compressed above, composed of five vertebral, eight lateral, and twentyfive marginal plates, which are marked by radiating and concentric striæ. A dorsal ridge is produced by the prominent posterior angles of the vertebral plates; the projections of the pesterior superior angles of the lateral plates also form, in some specimens, indistinct carinæ. The anterior marginal plates are narrow and oblong; the fifth, sixth and seventh are much wider, while the posterior three plates are marked with strong, concentric striæ, and the posterior angles form strong spinous points. The sternum is yellow, narrow, lozenge-shaped, composed of ten plates, and united to the nuarginal plates by a long narrow plate, having two smaller plates at its outer extremity. The head is very large, scaly above; eyes large ; jaws powcrful, hooked; beneath the chin, two warts; neck above, covered with warts or small fleshy cirrhi; beneath, granulated. The legs are large and strong; the fore legs are armed above with large scales, feet with five claws; hind legs with large scales beneath, feet with four claws. Tail, two thirds the length of the body; round at its base, compressed at the sides, tapering to a point; armed above by a ridge of strong pointed spines, diminishing towards the posterior extremity.

The largest living specimen 1 have seen, was taken at Marshfield; its dimensions were as follows: Entire length, 44 inches, viz. length of the shell, 18 inches; length of the head and neck, when extended, 11 inches; length of the tail, 15 inches. Width of the shell, 15 inches; width across the head, 4 inches. 


\section{Crstuda. Fleming.}

Generic characters. Shell gibbous, strong; marginal-plates twenty-five; sternum oval, covered with twelve plates, bivalve, both valves moveable on the same axis, and joined to each other and to the shell by ligamento-clastic tissue; anterior extremities with five, posterior with four nails.

\section{Carolina. Edwards. The Box Tortoise.}

Shaw's Gen. Zoology, vol. iii. pt. 1. p. 36, et fig.

Ann. Lyc. N. Y. vol. iii. p. 124.

Harlan's Med. and Plıys. Res. p. 149.

Dum. et IBibr. Hist. Nat. des Rept. tom. ii. p. 210 .

Bell, monog. Test.

I have received living specimens of this species through the kindness of friends from Barnstable, Amherst, New Bedford, Holmes Hole, and Walpole; and although at neither of these places is it common, yet their distances from each other shows that it is pretty widely distributed throughout the State. This is a land species, being found in dry and arid situations, and can live but a short time in the water. From the circumstance of the sternum being divided into two portions, the anterior of which is moveable, enabling the animal when disturbed, to encase-itself entirely within its shell, the species is gcnerally known under the name of "box tortoise." Several varieties have been made by naturalists dependent upon the difference of their marlings.

A beautiful living specimen hefore me exhibits the following characteristics :

Length of the specimen, six inches. Shell round, gibbous, carinated. Sternum bivalvular. The plates of the upper shell are of a dark brown color, sculptured with radiating and concentric strix, and covered over their entire surface with bright ycllow spots, varying in their size, form, and manner of distribution, frequently confluent. A great portion of each marginal plate is occupied by a yellow blotch. The first and fifth vertebral plates, are pentagona!; the second, third and fourth 
are hexagonal. Of the lateral plates, the posterior ars the smaller. The sharp edges of the seventh, eighth, ninth and tenth marginal plates, which are the largest, project outwardly, forming a keel. The sternum is divided unequally; the anterior portion the smaller; it is of a very dark brown color, with dull yellow blotches. The anterior plates of the sternum are triangular; the middle, ollong; the posterior, triangular. These plates likewise exhibit concentric striæ. Head above, black, reticulated with yellow; the upper jaw of a dull white color, with black lines passing from the eye to its margin. 'Throat white, with dark spots; flesh on the sides of the neck of a dull horn color, varied with red and brown. The upper jaw has a large hook-like process at its extremity; the lower jaw, a sharp point. Pupil of the eye, black; irides red. The fore legs are envered with large scales of an orange color, tipped with dark brown; posterior legs of an uniform dark brown color.

The principal food of this species is insects.

\section{Blandingii. Holbrook. Blanding's cistuda.}

N. A. Ilcrpetol. vol. iii. p. 35 et fig.

By the kindness of Mr. Edward Appleton I have received from Haverhill a fine living specimen of this rare species. It presents the following appearance: Length of the specimen $7 \frac{1}{2}$ inches; breadth of the shell 5 inches; length of the sternum, 7 inches; height 3 inches. Shell oblong, rounded, slightly flattened above. The plates of the upper shell are black, covered with mumerous bright yellow circular and oblong spots or blotches, irregularly distributed. 'The first vertebral plate is pentagonal; the second and third are hexagonal; the fourth is heptagonal; the fifth is octagonal. Of the lateral plates, the anterior and posterior are quadrilateral, the third and fourth, pentagonal. The marginal plates are twenty-five in number; the nuchal plate is very small, about a line in width, and less than half of an inch long; the first, third, 
fourth, sixth, eighth, tenth, and twelfth plates are quadrilateral; the second, fifth, seventh, ninth, and eleventh, pentagonal; the edge of these marginal plates is sharp and entire. The sternum is composed of two valves, the posterior of which, the larger, is oblong, rounded before, emarginated bchind; both valves are moveable, and when closed they shut the animal entirely with the exception of his toes. The sternal plates, twelve in number, are yellow, with large quadrangular dark spots, occupying nearly one half of each plate; the plates are marked with concentric striæ.

The head is nearly black, with yellowish spots. The upper jaw is of a dark brown color, with transverse yellowish lines; the lower jaw is of a bright yellow. The anterior extremities are protected by large imbricated scales in front, with smaller ones beneath, and granulations behind; there are five fingers, which are palmated, with nails. The posterior extremities are larger than the anterior, of the same color, and, like them, having scales and granulations; these extremities are flattened upon the leg and foot, with 5 toes; the posterior only destitute of a nail. Tail cylindrical, gradually tapering to a point.

In regard to this species, Dr. Holbrook, in the third volume of his Herpetology, which is just published, observes: "The sole locality that can at this moment be assigned to the Emys Blandingii, is the prairies in the state of Illinois and the territory of Wisconsin, where they are said to be abundant. The only specimen I lave seen came from Fox river, a tributary of the Illinois."

Sphargis. Merrem.

Generic characters. Body covered by a leathery skin, tubercular in the young, perfectly smooth in the adult. Feet without nails. 
S. coriacea. Lin. The Leather Tortoise.

\section{Plate IV.}

Pennant's British Zoology, vol. iii. p. 7, et fig.

Slaw's Gen. Zoology, vol. iii. p. 77, et fig.

Phil. 'Trans. vol. Ixi. pt. 1. p. 2‡1, et fig.

Duin et Bibr. Hist. Nat. des Rept. t. ii. p. 561.

The only specimen I have heard of having been seen on the coast of the United States, was taken asleep on the surface of the water in Massachusetts Bay, in the year 1824, and being brought to Boston, was purchased by Mr. Greenwood of the New England Museum, of the captors, for two hundred dollars, and placed in this institution, where it still remains. The naturalist may judge of the great rarity of this species from the following observations by Dumeril and Bibron, in their "Erpétologie générale ou Histoire Naturelle complete des Reptiles ;" "This species is very rare; it inhabits the Mediterranean, and the Atlantic ocean. Rondelet speaks of a "Sphargis luth" five cubits long, which was taken at Frontignon: Amoreux described another which was captured in the harbor of Cette; and in 1729 a third was taken at the mouth of the Loire, which was described by Delafout in the "Mémoires de l" Académie des Sciences." Borlase has given a bad figure of a "Splargis luth," which was taken in 1756 upon the coast of Cornwall, in England."

The specimen in the New England Museum presents the following characters: Entive length eighty-five inches; widest part, fourteen inches; back of the head, thirty-four inches; greatest depth fourteen inches. The body is covered akove, by a dark brown' shield, fifty-seven inches in length, of a firm leathery texture, which is divided into furrows by seven longitudinal elevated ridges; all these ridges are noduled, resernlling the vertebral column; the dorsal ridge runs the whole length of the shell ; those on the side, next the dorsum, commence one inch and a half further forwards than the dorsal ridge, and within sixteen inches of the posterior extremity of 
the shell curve upwards towards the dorsal ridge, but are not as perceptible after curving, and reach the upper ridge, six inches anterior to the extremity of the shell. 'The second lateral ridge commences about seven inches back of the preceding, and, at the posterior extremity, curves up like that ; the abdominal margin makes the third lateral ridge. The posterior extremity of the shell is truncated, and is two and a half inches wide.

Length of the head and neck, sixteen inches: of the head, nine and a half inches; width of the head nine inches; width of the neck, thirteen inches. Diameter of the eye, large. Nostrils just back of the tip of the snout. A large notch in the middle of the upper jaw, which receives the projections of the lower jaw, when the mouth is elosed; on each side of this median emargiration of the upper jaw are two others, one on each side of it. Upon the middle and posterior portion of the roof of the mouth, strong spinous processes.

A portion of the œsophagus of this specimen belongs to the cabinet of the Boston Society of Natural History ; it is compactly armed with long firm very sharp spines.

Anterior extremities, thirty-five inches long, rounded at the origin, compressed in the middle, tapering to a rounded extremity; in their widest portion, ten inches across.

Postcrior extremities, sixteen inches in length; for about half their length, nine inches wide, truncated postcriorly, and, as well as the anterior extrenities, bordered upon their posterior margin by a deep fleshy fringe or border.

Length of the tail, thirteen inches; eight inches wide at the base, tapering to a point.

Body beneath, covered by a less firm envelope, of a lighter color.

I am indebted to my friend Dr. Wyman for the accompanying plate of this species. 


\title{
OR DER I I.
}

\author{
SAURIA.
}

Fanily.

\section{SCINCOIDEA.}

\section{Scrncus. Daudin.}

Generic characters. Head oblong, pointed, covered with plates; jans furnished with closely set teeth; two rows of tecth on the palate; tongue fleshy, slightly extensible, omarginate; tympanum apparent; nerk as large as the head; body elongated; tail conical; the whole body and tail covered with small imbricated scales; extremities with free and unginculated toes.

S. fasciatus. Lin. The Blue-tailed Lizard.

Shav's Gen. Zoolngy, vol iii. pt. 1. p. 241.

Harlan's Mled. and l'hysic Res. p. 138.

N. A. Herpet. vol. iii. p. 45, et fig.

The only specimen of this beautiful species I have known to be found in New England, was captured in Barre, by Dr. Joseph N. Bates of that place, and kindly loaned me to identify and describc. He took it, he writes me, "in a mud hole; it evaded my attempts to capture it for some time on account of its agility and cunning, and when captured made much resistance with jaws, claws, \&c."

Length of the specimen five inches, elongated, covered above with longitudinal rows of imbricated scales; color above, a deep shining black, with five longitudinal deep golden ycllow lines; abdomen, of a light yellow color; tail, a decp 
sky blue, blended with yellow and black lines, which run longitudinally along the back.

A yellow line commencing over each nostril, passes obliquely backwards, and, approaching each other, they unite at the distance of rather more than a quarter of an inch back of their origin, forming a dorsal line, which, continued the whole length of the body, is lost upon the tail; on each side of this dorsal line, runs another, which arises at the superior anterior angle of the eye, and terminates like the preceding; beneath this, is still another, commencing at the snout, and interrupted only by the meatus of the ear, is continued like the others upon the tail. These yellow lines give the back the appearance of being divided into yellow and black longitudinal lines. Head, half an inch long; one quarter of an inch wide; with large plates above. Eyes, small. External meatus of the ear, vertical, large. Anterior feet short, with five toes, each armed with a sharp nail. Posterior extremities, large; second toe very much elongated, and all the toes, like those of the fore feet, nailed.

Extremities above, of a brown color, having a longitudinal yellowish white line running along their posterior portion to the toes.

The vent is transverse, situated just back of the interior of the thighs. Tail longer than the body, its posterior portion a deep blue.

The species feeds upon insects. 


\title{
O IR E R III.
}

\author{
OPHIDIA.
}

\section{Familit.}

\section{SERPENTIA.}

\section{Cosuber. Lin.}

Generic characters. Body long, cylindrical and tapering; head oblong, covered above with smooth polygonal plates; above covered with rhomboidal scales, imbricate, reticulated, or carinated, or smooth; abdomen with transverse plates; beneath the tail with double plates; anus transverse, simple; jaws furnished with sharp teeth; without poisonous fangs. Some species oviparous, others ovo-viviparous.

\section{C. sirtalis. Lin. The Striped Snake.}

Shaw's Gen. Zoology, vol. iii. pt. 2. p. 535.

IIarlan's Med. and Phys. Res. p. 116.

This pretty species, generally known as the striped snake, is our most common snake. The usual length is about two feet; occasionally it is met with two feet and a half long. The upper part of the body is of a dark olive brown color. A narrow yellow band extends from the occiput to the extremity of the tail ; on each side of this, joining the abdominal plates, is a somewhat broader parallel band of the same color. The brown color of the back is variegated with black blotches, which are much more strongly marked in the smaller specimens; in the larger specimens, they are hardly discernible, unless the scales be slightly separated by the observer. Abdo- 
men greenish; its upper portion towards the sides, lighter; the posterior edge of the abdominal scales, at their union with those of the sides, marked with a black spot; at the distance of one or two lines within this spot, towards the centre of the abdomen, another spot is observed, which in young specimens is equally dark with the former, but duller in old specimens. Scales oblong, strnngly carinated; smaller upon the back of the head and the upper anterior portion of the body, than farther back. Scales of the yellow lateral lines, larger than those of the olive colored back. The scales that are shortest, least carinated, and at the same time the largest, are in a single row between the abdomen and the lateral line referrcd to. Head flattened, having upon its top ten plates; one at the snout, 1 wo pairs behind this, three between the eyes, and two, larger than either of the preceding, upon the occiput. Pupil of the eye, black; iris, reddish. Upper jaw margined on each side by seven plates, besides that at the tip ; the fifth, situated directly beneath the posterior angle of the eye, the largest. Lower jaw bordered by ten plates on each side. Two pairs of plates upon the throat, very much elongated. Small teeth in the jaws and upon the palatine bones.

'The bright yellow color, which renders this a beautiful species when alive, changes to a dull greenish yellow after being immersed in spirits; in this state, it appears to have been described by Herpetologists. When the scaly cuticle is removed, the dorsal line heneath is found to be white; and the sides of the back are of a deep blue color, with two rows of black, nearly circular blotches. Sometimes the line on the back is a greenish white, while the lateral bands are yellow. Upon the occipital plates of one of my specimens are two small yellow spots towards their middle at their interior edges. The brightness of the lateral lines disappears at the anus; beyond, the color is greenish, and this is gradtially lost towards the tail.

Linnæus describes his species as having 150 abdominal plates, and 114 caudal scales; Shaw copies this in his "General Zoology." Harlan makes 150 plates, and 60 caudal scales. 
One specinen before me, has 154 plates, and 75 scales; a second specimen has 146 plates, and $6 \ddot{3}$ scales.

This species feeds upon frogs and toads, and is frequently found enormously distended by having swallowed one of a very large size.

\section{C. ordinatus. Lin. The little brown Snake.}

Shaw's Gen. Zoology, vol. iii. pt. 2. p. 497.

Harlan's Hed. and Phys. Res. p. 113.

'This is also quite a common sprecies with us, growing to thic length of two feet. The color above, is a browish ash, witl a broad, lighter ash-colored longitudinal band upon the dorsal ridge, rumning the whole length of the animal ; on cach side of this dorsal band, a row of small dark brown spots. Body beneath, fawn-colored; of a darker tint upon the sides. A row of very minute black dots upon the outer edge of the abdominal plates. Scales small; carinated; a row of scales larger than the rest, upon the sides. joining the abdominal plates. Head very small, flattencd above; with ten scales upon its top, the two upon the occiput, and that directly in the middle of the top of the head, the largest, and black; the others are quite small, and of the color of the back; these seales are arranged as follows: Two triangular ones upon the occiput; a third, hexagonal in its form, in front of them; its postcrior portion, between the anterior inner portion of the former, making the top of the head; on each side of this, protecting the top of the eye, a small oblong scale, rounded upon its outer edge; in front of these, immediately back of the eye, two fairs of quadrangular scales; the posterior, larger. A single large scale forms the snout. Besides these scales, three are seen in front of the eye, on the side of the head; and quite a large scale back of the posterior angle of the eyc, separated from it by two very minute scales only. Upon the margin of the upper jaw, fourtcen scales; upon the edge of the lower jaw, twelve, besides the tip. An oblique black band passes downwards 
across the angle of the jaws, and a transverse one back of the occipui, crosses the neck on each side; in some specimens all the scales upon the upper jaw are edged with black.

Sometimes the spots on the sides of the abdomen are very distinctly seen; in others, as in several specimens lying before me while I write, they are scarcely observable.

When preserved in spirit, the longitudinal dorsal line becomes lighter colored, and the abdomen changes to a yellowish green color.

The abdominal plates are 128 ; the caudal scales 62 and 64 .

In the stomach of this species, I have found fragments of insects.

\section{C. vernalis. Dekay. The green Snake.}

Harlan's Med. and Phys. Res. p. 124.

One of our most beantiful species, this snake is generally well known. A fine living specimén before me, twenty-one inches in length, exhibits the following characters :

Above, of a beautiful grass green color; beneath, a yellowish white. Length of the head, half an inch; greatest width of the head, a quarter of an inch; head flattened above; ten plates upon the top of the head; one at the snout; two pairs immediately back of this; three plates between the eyes; two large plates upon the occiput. Upper jaw bordered by fourteen scales. Nostrils circular, just back of the posterior lateral angle of the snout. Pupil of the eye, black; iris cupreous. Scales rhonıboidal, smooth, not carinated. Tail six inches in length, gradually tapering to the point.

Four sfecirnens vary in their plates and scales as follows:

One specimen has 137 plates ; 85 caudal scales.

$\begin{array}{lllllll}\text { A sccond } & \text { " } & 132 & \text { " } & 80 & \text { " } & \text { " } \\ \text { A third } & \text { " } & 133 & \text { " } & 81 & \text { " } & \text { " } \\ \text { A fourth } & \text { " } & 127 & \text { " } & 84 & \text { " } & \text { " }\end{array}$

Like the preceding species, this feeds upon insects. 
C. punctatus. Lin. The ringed Snake.

Shaw's Gen. Zoology, vol. iii. pt. 2. p. 553.

Harlan's Med. and Phys. Res. p. 117.

N. A. Herp. vol. ii. p. 115, et fig.

This pretty species is less common than either of the preceding, being usually found concealed beneath the bark of decaying trees. The specimen before me is fourteen inches in length; the body is elongated, with smooth scales. Color above, of an uniform bluish brown; beneath, of a reddish yellow, with a longitudinal row of black spots upon each side of the abdomen, where the abdominal plates and lateral scales unite; a third row of similar spots runs longitudinally along the middle of the abdomen, as far as the vent, beyond which they are not visible. Ten plates upon the top of the head; sixteen plates, beside that at the tip, border the upper jaw ; and fourteen, margin the lower. Head half an inch long, one quarter of an inch wide; flattened above; rather lighter colored than the body. Nostrils large. Eyes of moderate size; pupils black, irides grayish. A broad yellowish white band crosses the occiput. Tail, three inches in length, tapering to a point. The abdominal plates are 156, and the caudal scales 56. A second specimen exhibits 156 plates, and 62 scales.

C. constrictor. Lin. The common black Snake.

Shaw's Gen. Zoology, vol, iii. pt. 2. p. 464.

Harlan's Med. and Phys. Res. p. 112.

In some parts of the State, this is not an uncommon species, frequently growing to the length of six feet. A fine specimen, fifty-one inches in length, serves for the following description: Length of the head, one and a half inches; greatest width of the head, half an inch. Body, above, almost black; beneath, slate-colored; neck, margin of the jaws, and snont, yellow. Plates upon the top of the head, very large; that at the snout, 
convex, projecting, yellow, bordered with black at its upper and lateral margins; the first pair of plates, nearly quadrangular; the second, pentagonal; of the three between the eyes, the middle, which is largest, is hexagonal ; those at the sides of this, over the eyes, are pentagonal ; the two posterior plates, pentagonal. Sixteen plates border the upper jaw. Eyes large. Nostrils large, vertical, situated between the second and third plates, back of the snout. 'Three pairs of elongated plates on the throat, just back of the chin; back of these plates, two pairs of smaller plates anterior to the abdominal plates. The whole back covered with large rhomboidal smooth scales. Body somewhat compressed at the anterior extremity ; cylindrical at the posterior, gradually tapering to the tail, from which it more suddenly becomes smaller, and terminates in a point. Length of the tail, eleven inches.

The abdominal plates are 184 ; the caudal scales, 85 .

This species is generally met with in wild and unfrequented places; it is avoided as venomous by many, although perfectly harmless. It feeds upon the toad, and several species of frogs ; oftentimes it catches small birds. Mr. Erastus H. Clap informs me that he saw one that had swallowed a common sized specimen of the Robin, "Turdus migratorius," entire ; it is said also to prey upon the different species of meadow mice.

\section{C. amaenus. Say. The red Snake.}

Journal Acad. Nat. Sciences, vol. iv p. 237.

Harlan's Med. and Phys. lies. p. 118.

A single specimen of this specics has been received from Professor Adams, who found it at Amherst; this specimen being preserved in spirits, and its natural character somewhat affected thereby, I avail myself of the very accurate description of Say :

"Body above, reddish brown; beneath, vivid red; head not larger than the neck, obtusely rounded before; terminal plate curving a little on the top of the head, so as to be nearly hori- 
zontal above; first pair of plates rather short, breadth decidedly more than double the length; second pair rather large, oblique, posterior outer angle reaching the eyes; central plate convex, rounded; subtri-angular, wide before and angulated on the anterior middle, posterior angle acute; postcrior plates a little convex, with a single scale betwecn their tips; eyes with one scale behind, one before twice as long as the posterior one, small plate above the eye less than half the length of the central plate, and not twice as large as the posterior eye plate; teeth minute; scales smooth, polished, somewhat opalescent, slightly convex, rounded at the tip; tail less than one seventh the whole length; tip rather abrupt, conic, solid, acute.

Plates, 124 ; scales, 25. Total length, ten inches and three tenths; tail, one inch and two fifths.

Var. a. dark slate color above.

A pretty and perfectly harmless serpent. The contrast of color betwcen the lively red, sometimes rosaceons, of the inferior surface of the body, and the brown, more or less deep, of the superior surface, is very striking; the abrupt termination of the tail and the narrow head, are also distinguishing traits. It is found beneath stones and prostrate logs, but not very frequently."

My specimen is seven inches long; tail, one inch; abdominal plates, 136 ; caudal scales, 32.

\section{C. eximius. Dekay. The chicken Snake.}

Harlan's Med. and Phys. Res. p. 123.

This not very uncommon species, is known by the names of house snake; thunder and lightning snake; chicken snake; milk snalie; and chequered adder. It is one of our largest species, measuring sometimes five feet or more in length ; and is a beautiful snake. A specimen thirty-four inches in length, furnishes the following description: Body elongated, varying very little, 
in its circumference anterior to the tail, but back of the vent, rapidly terminating in a point; all the upper portion of the body covered with smooth rhomboidal scales. Body, above; of a dark brown color, with numerous transverse white bands, which become confluent on the sides; the brown portions of the back. between these transverse bands, irregular in their form, and margined with black; blotches of a similar color with the back, along the sides. Abdomen yellowish, variegated with quadrangular black spots. Circumference of the head less than that of the body; length of the head, one inch; width across the head, half an inch. The plate at the snout large, with a well marked emargination beneath; the first pair of plates moderate in size, quadrangular; the second pair of plates also quadrangular, and much larger ; the central plate on the top of the head large, pentagonal; those upon the sides of this, irregularly quadrangular; occipital plates very large. Fourteen plates margin the upper jaw ; sixteen plates edge the lower; these plates on the jaws are yellow, margined with black. Eyes moderate in size; from their posterior angle, a black band passes obliquely backwards. Upon the neck, seven longitudinal plates, between the chin and the abdominal plates; the anterior three, largest; the second, larger than any. Length of the tail, four inches.

The abdominal plates are 207; caudal scales, 48.

'This species feeds upon toads and frogs.

\section{C. sipedon. Lin. The water Adder.}

Shaw's Gen. Zoology, vol. iii. pt. 2. p. 496.

Harlan's Med, and Phys. Res. p. 114.

Large numbers of this species are found in mowing meadows which are overflowed a part of the season; it is frequently killed at Cambridge, four feet and more in length; its body being the size of a man's wrist. By many it is avoided, as being poisonons in its bite. The body is large; its circumference lessening but little, anterior to the vent; rapidly 
tapering posterior to the vent; of an uniform dark brown color above; reddish upon the sides; abdomen yellowish white, mottled with dark brown; beneath the tail, nearly black. Whole upper part of the body covered with rows of elongated, strongly carinated scales; these carinæ, more obvious upon the posterior extremity; nothing peculiar in the arrangement of the plates upon the head; the ten plates upon the top of the head, of moderate size ; sixteen plates upon the upper jaw ; eighteen plates upon the lower jaw. Eyes prominent. Nostrils of moderate size.

The abdominal plates are 139 ; caudal scales 72.

In a young individual lying before me, seventeen inches in length, with the same number of abdominal plates and caudal scales with the above described specimen, the back is crossed transversely by a large number of ycllow bands, and the scales on the tail are so strongly keeled, as to produce well marked grooves between the rows of scales.

This species feeds upon frogs.

\section{C. saurita. Lin. The riband Snake.}

Shaw's Gen. Zoology, vol. iii. pt. 2. p. 5:32.

Harlan's Vled. and Phys. Res. p. 115.

This beantiful little snake is not very common; it resembles somewhat the sirtalis, but it is smaller, lighter colored, and much more graceful in its figure and proportions. Its form is very slender, tapering to an acute point. Above, dark brown, with three longitudinal stripes of a greenish white cclor, which are very distinct as far as the vent, back of which they are insensibly effaced; both sides of the dorsal line, and the upper edge of the lateral lines, margined with black. Whole length of the specimen before me, ten inches; length of the tail, three and a half inches. The scales upon the top of the head are moderate in size; fourteen upon the upper jaw, twenty upon the lower jaw. Eyes rather large.

The abdominal plates are 162; caudal scales 112. 


\section{C. occipito-maculatus. Nobis. The spotted-neck Snake.}

This pretty species, which I suppose to be undescribed, was received from Professor Adams, who found it at Arnherst. It was sent me in spirits, and therefore it is probable that its colors had somewhat changed. Its length is ten inches and a half; length of the head, less than half an inch; width across the head two lines. Body elongated, covered with longitudinal rows of pentagonal scales, connected, and at their posterior extremity, slightly fissured. All the upper portion of the body, a light ash or gray color. An indistinct band of a lighter color passes longitudinally down the back; this is margined on each side with a row of dark colored, almost black scales; on each side of the body, a row of larger scales than those upon the back, unite the back with the abdominal plates; these scales are black, with a longitudinal delicate white line passing through their centres. Abdomen yellowish white, with black or fuliginous markings upon the outer edge of the plates, appearing upon the anterior plates like black dots. Circumference of the neck less than the remainder of the body; body largest just anterior to the vent; back of the vent it more rapidly approaches a point. The three anterior plates upon the head, viz. that at the snout, and the two pairs inımediately posterior to this, yellow ; the other plates the color of the back, variegated with white. 'Twelve plates upon the upper jaw, besides that at the snout; fourteen plates margin the lower jaw, besides that at the chin. Three large white irregularly formed blotches, directly back of the occipital plates; one above, and one on each side of the first.

There are 124 abdominal plates, and 38 caudal scales.

In as much as the "punctatus" sometimes exhibits merely a spot upon the occiput, instead of a circular band, the superficial observer might think that, and the species I have just described as identical; a little attention will show the marked differences between them. 
Heterodon. Palisot de Beauvais.

Generic characters. Plates and scales as on the Colubri; the rostral plate a trihedral pyramid, with a ridge above, and pointed at the tip; posterior maxillary teeth largest.

H. platirhinos. Iatreille.

Daud. Hist. Nat. des Rept. tom. vii. p. 153.

Harl. Med. and Phys. Res. p. 120.

N. H. Herpetol. vol. ii. p. 97, et fig.

I have never seen a specimen of this animal ; but Dr. Holbrook assures me he possesses an individual which was captured at Medfield. His description therefore is here introduced: "The head is large, flat, triangular, broad behind, with the snout pointed and elongated at the tip; it is covered with scales on the posterior part, and with plates on the anterior and on the vertex. The vertical plate is regularly pentagonal, with its broadest point directed forwards. The superior orbital are quadilateral, elongated, and broadest posteriorly, with their outer margins projecting over the eye, which gives a sinister look to the animal. The occipital plates are rhomboidal. The frontal are quadrilateral, with their anterior inferior angles very much prolonged; the anterior frontal are triangular, with their bases directed inwards, and their apices rounded, and turned to the nostrils. Between these frontals, so as to prevent them coming in contact with each other, is a narrow elongated azygos plate, reaching from the posterior frontal to the rostral plate, with a ridge on its upper surface, continuous with that of the rostral plate. The rostral plate is triangular, with its basis below and the apex very pointed above, and recurved, with a strong carina or ridge on the upper surface. The nostril plates are two on each side; the anterily quadrilateral, lunated on the posterior margin, with its anterior and inferior angle greatly prolonged; the posterior is narrow, and concave in front to complete the nostril. There are twelve orbital plates, the superior of which have been already described. Besides these there are three anterior orbital plates, 
which are quadrilateral, the largest being above; the inferior orbital are five, and the posterior orbital three in number, all of which are quadrilateral. The upper jaw has six lateral plates, quadrilateral, and increasing in size to the sixth, which is largest. The nostrils are very large, near the snout, and lateral. The eyes are large, the pupils dark, the iris light gray. The neck is nearly the size of the head when he is quiet, but when roused or irritated he flattens it more than twice its ordinary breadth. The borly is elongated, thick, rounded above, but flattened at the abdomen, covered with scales strongly carinated above, the three inferior lateral rows being ecarinate, and with plates below. The tail is long, narrow, and terminating in a point, with scales or bifid plates on its under surface.

Color. The head above is dusky, with a light band between the orbits; behind the occiput is a dark spot; a dark band begins at the back of each nostril, which increases in size as it descends, and forms a large blotch on the side of the neck. The body is olive-brown, or sometimes brownish yellow, and marked with a triple series of black or dark gray spots; those of the vertical series being subquadrate and elongated transversely; the spots of the lateral rows are rounded, and many of them correspond with those of the vertebral line, while others alternate with them. Sometimes the spots of the lateral and vertebral lines are confluent, so as to give the appearance of bands.

Dimensions. Length of the head, 1 1-2 inches; breadth of the head, when not disturbed, 1 inch; length of the body, 27 inches; length of the tail, 5 inches; circumference of the body, 4 1-2 inches. In the individual here described, there were one hundred and forty-four abdominal plates entire, and two bifid plates near the vent; and forty-two pair of subcaudal scales." 


\section{Crotalus. Lin.}

Generic characters. Head large, triangular, rounded in front, covered with plates anteriorly; vertex and occiput with scales; a deep pit between the eye and nostril; upper jaw armed with poisonous fangs ; body elongated, thick; tail short and thick, terminating in a rattle, which is a corneous production of the epidermis; plates on the abdomen, and under the tail.

C. durissus. Kalm. The banded Rattle Snake.

Turton's Linnæus, vol. i. p. 672.

Shaw's Gen. Zoology, vol. iii. pt. 2. p. 317, et fig.

Harlan's Med. and Phys. Res. p. 132.

N. A. Herpetol. vol. iii. p. 81.

This species, which is generally known in New England as the rattle snake, is extensively distributed throughout the State. Two fine specimens, taken at Douglas the last summer, gave me an opportunity for minute observation. One of them measured three feet and one inch in length, and was five inches in circumference; the other was three feet long. From the former, I drew up the following notes:

Upper part of the body, of a yellowish brown color, with rhomboidal black spots continued along the back, margined with bright yellow; upon each side of these rhombs a black band is continued to the sides of the body, where it terminates in an irregularly quadrate black spot; tail black. Body, beneath, yellow, with fuliginous dots and blotches distributed irregularly over its surface. Scales on the back elongated, carinated; scales upon the sides larger, carinæ less prominent. Length of the head, one incl and a half; width of the head, one inch. Top of the head, flattened; scales upon the top, small; on the sides of the head, large, pentagonal; on the edges of the jaws, quadrangular. Snout, terminated by one large plate; a quadrangular plate on each side of this ; directly back of these, a smaller one, in which are the circular nostrils, situated obliquely, pointing forwards. Directly 
above the two lateral plates, two others are situated; the first, meeting the snout anteriorly, and the second, extending some distance beyond the nostrils behind. At the anterior angle of the eye, a large plate, separated from the nostrils by two quite small plates, at the anterior inferior angle of which, is the aperture for the poison. A large plate over the eyes. Two plates much larger than the others, upon the throat.

The rattle is composed of six corneous portions. The other specimen has eleven rattles. The abdominal plates are 170 ; caudal plates, 24 .

Although the poison of this species is very virulent, an accident is seldom known to occur; proving its unwillingness to be the aggressor, and that the fangs are used only as weapons of defence, after sufficient warning has been given of its presence, by the rattles.

The general impression that a rattle is added annually is incorrect. Dr. Holbrook observes, "It is now certain that rattle snakes have been known to gain more than one rattle in a year, and to lose in proportion, the exact number being regulated no doubt by the state of the animal as to health, nourishment, liberty, \&c. I have known two rattles added in one year, and Dr. Backman has observed four produced in the same length of time."

The power of fascination attributed to this genus, is too absurd to require our serious consideration. 


\title{
ORDER IV.
}

\author{
BATRACHIA.
}

RANA. Lin.

Generic characters. Body covered with a smooth skin; upper jaw furnished with a row of minute teeth; another interrupted row in the middle of the palate; no post-tympanal glands; posterior extremities long; and in general fully patmated; fingers four; toes five in number.

\section{R. pipiens. Lin. The Bull-frog.}

Shaw's Gen. Zoology, vol. iii. pt. 1. p. 106, et fig.

Harlan's Med. and Phys. Res. p. 101.

N. A. Herpetol. vol. iii. p. $\varepsilon 1$, et fig.

This is by far our largest species of frog; it inhabits ponds, ditches, and pools of stagnant water, but is not common in this portion of the State.

A specimen lying before me twelve inches in length, serves for my description. Greatest width nearly three inches. Color above, a light green, with sparse dusky spots upon the back; head green. Sides of the body, brownish; beneath, white; throat yellow. Legs, more or less barred with dull transverse bars. Fore legs, including toes, three inches in length; above, of a dull greenish brown color, with indistinct brownish transverse bands; beneath, white; four toed, that next the outer, the largest, each with three small tubercles at the joints of the phalanges. Posterior extremities, seven and a half inches long, of a similar color with the anterior extremities; the upper anterior half of the thighs barred with brown bands; the upper posterior portion, greenish brown, with an in- 
termixture of a duller brown color, with small white spots or blotches; legs with four transverse brown bands; indistinct bands on the feet; five toed, that next the outer, much the largest, being two and a half inches in length; toes palmated; and tubercled like the toes of the anterior feet; at the base of the little toe, is a prominent projecting carina along the edge of the phalangeal ridge of the largest toe; a row of yellow dots run to the second phalanx.

Length of the head, one inch and a half; width across the tympanum, two inches. Eyes prominent, large; pupils black; irides greenish yellow; distance between the eyes, three lines. Snout obtuse and yellowish, as well as the margin of the upper jaw. Nostrils about a line in length, situated obliquely, half way between the tip of the snout and the eye, appearing like two small black points. Tympanum half an inch in diameter, plane, looking like a large scale fastened to the head; just within its outer margin, a brownish circular ring; within this ring, greenish. Mouth large; numerous small sharp teeth in the upper jaw. Tongue large, fleshy.

In the stomach of this specimen, taken in Muddy Pond, Roxbury, I found five specimens of the "Helix albolabris," with the contained animal; one only was perfect, the others being more or less digested; this specimen measured one inch in its greatest diameter, and was five lines in height.

This species usually feeds upon frogs and insects, and the farmers assert that it sometimes robs them of their chickens.

R. fontinalis. Leconte. The Yellow throated green Frog.

Ann. Lyc. N. Y. vol. i. p. 282.

Harlan's Med. and Phys. Res. p. 103.

N. A. Herpet. vol. iii. p. 85, et fig.

This species appears very early in the spring, and continues extensively distributed throughout the season. It may be at once recognised by its greenish color, and yellow throat. Length of the specimen before me, three inches; length of the posterior extremities, four inches and a half. Head and 
upper part of the anterior portion of the body, of a brilliant green color; posterior portion of the body slightly maculated, greenish, mixed with brown; sides granulated, brown, mottled with irregularly formed and distributed black blotches; beneath the throat, yellowish; abdomen white. Head one inch long; snout blunted and yellowish at the extremity. Eyes very prominent; pupils black; irides metallic, encircled by a brilliant golden ring. Nostrils nearer to the eyes than to the mouth. Gape of the mouth large, upper jaw with many minute teeth. Tympanum plane, circular, rust colored; four lines in diameter. From the posterior angle of the eye a cuticular fold extends just over the tympanum, along the edge of the back on each side, to the posterin part of the body.

Anterior feet fawn colored above, with several indistinct transverse brownish bands; a dark colored band along the posterior edge of the leg, extending on to the sole of the foot. Feet four toed.

Posterior extremities of a darker brown color than the anterior; thighs with indistinct bars upon their outer portions; buttocks covered over their whole surface with irregularly distributed black blotches; beneath, a dull white ; legs and feet, same color as the extremities of the thighs. Feet five toed.

\section{R. halecina. Kalm. The Leopard Frog.}

Shaw's Gen. Zoology, vol. iii. p. 105.

Journal Academy Nat. Sciences, vol. v. p. 337.

N. A. Herpet. vol. i. p. 89 , et fig.

This most beautiful species, called by Kalm the shad frog, from its appearing in Pennsylvania in the spring of the year, with the shad, is better known in this state as the leopard frog, from its ocellated appearance. It is exceedingly well marked, and considered by all a very pretty animal.

The upper part of the back, and external side of the limbs, brassy, with a metallic lustre. Upper surface of the body, marked with large distinct irregular spots or blotches which 
have a brownish centre, a black circumference blending with each other, and a bright green halo; generally there are two longitudinal rows of these blotches, which are continued the whole length of the body; sometimes these spots are very regular, at other times, a third row may be seen, or the two will have become confluent at their inner sides, or the spots in the sarne row will have united with each other. Throat and abdomen white. Eyes prominent; pupils black; irides golden. On each side of the back, an elevated bronze colored ridge passes from the eyes to near the extremity of the body. A similar, but smaller ridge runs from the anterior angle of the eye to the snout. On the onter side of the thighs, legs and tarsus, the blotches are long, irregular, but arranged transversely, having the appearance of bands. Buttocks and posterior surface of the thighs granulated and mottled with black. Upper surface of the body finely corrugated with several irregular cuticular folds, arranged longitudinally on the back. Throat and belly smooth. Feet palmated; the fourth toe much larger than the others. All the fingers and toes with tubercles on the inner surface of the joints. The body of this species seldom exceeds four inches in length.

'This frog is generally found in damp places, a short distance from water ; although, being a great leaper and hence enabled to reach its wonted situations with ease, it is occasionally met with at considerable distance from any pond or brook.

R. palustris. Leconte. The Pickerel Frog.

Ann. Lyc. N. Y. vol. i. p. 282.

Marlan's Med. and Phys. Res. p. 105.

N. A. Herpet. vol. i. p. $9: 3$.

Although Leconte applied the specific name of "palustris" to this quite common species, on account of its being found near salt marshes, it is as frequently, in this vicinity at least, met with about the margins of fresh water brooks and ponds, as in any other situations. It is a prettily marked species, but much less brilliant in its colors than the preceding. 
'The largest specimen I have met with, measured three inches in length; and the posterior extremities were four inches and a half long. Color above, cinereous; abdomen white; interior of the limbs and lower part of the flanks, yellow. Upon the back, two longitudinal rows of dark brown spots, which are generally square, sometimes nearly circular; in some specimens, these becorne confluent and produce an elongated band; in the same specimens, both square and circular spots may occasionally be observed. Between the back and sides, a broad yellowish brown band is seen, commencing at the eyes, and extending the length of the body. Two rows of smaller spots of a similar appearance with those on the back and sides. Snout, pointed. Eyes rather prominent; pupils, black; irides, golden. Tympanum, small, color of the back; a dark colored line extends from the snout to the eyes, a roundish spot on the upper and inner side of each orbit, one on the top of the head, and a smaller one below each nostril. Thighs, legs, and tarsus, striped transversely with broad dark bands or oblong spots; arms irregularly spotted. Back, smooth; flanks slightly tuberculated; buttocks, granulated; fleshy tubercles on the lower surface of the toes at the joints.

\section{R. sylvatica. Leconte. The Wood Frog.}

Lyc. Nat. Hist. N. Y. vol. i. p. 282.

N. A. Herpet. vol. i. p. 95, et fig.

This beautiful species is not often met with, inhabiting as it does damp and thick woods; occasionally it is seen at a great distance from any water, and is very difficult to be taken on account of its agility in leaping. It is rather smaller than the "palustris," and presents the following characters: above, of a reddish brown color, resembling a dried dead leaf; sides, variegated with green and yellow; abdomen, white; under part of the arms and posterior extremities, lighter colored than the back. Snout, blunted. Eyes, prominent ; pupils, black ; irides, golden. A broad black band, narrow at its origin, wider at its 
posterior portion, extends from the suout to the shoulder: this band passes through the centre of the eye, including within it, the tympanum; margining the lower edge of this band, is a deep yellow line running its whole extent. Extremities above, rather lighter than the back; the anterior extremities are seldom banded; the posterior extremities, crossed by transverse dark colored bands. Anterior extremities, four toed ; posterior, five toed.

Like the three preceding species, this frog feeds principally upon insects.

\section{Hylodes. Fitzinger.}

Generic characters. Mouth furnished with a tongue, teeth in the superior maxillary and palatine bones; tympanum, visible; extremities slender, tips of the fingers and toes terminating in slightly developed tubercles.

\section{H. Pickeringii. Pickering's Hylodes.}

N. A. Herpet. vol. ii.

Rev. John L. Russell, of Salem, showed me the only specimen of this species I have ever seen, which was captured by Dr. Nichols, in Danvers. Having no opportunity to describe it myself, I extract the following account from the pages of the "Journal of the Essex County Natural History Society."

"Above, fawn color, changeable to dark cinereous; marked with two transverse narrow black lines, forming a cross, and an irregular narrow line on each side, producing, with the other lines, a general rhomboidal configuration; a large triangular spot on the back of the head, formed by the junction of lines proceeding from the centre of the irides; a spot at the insertion of the fore legs; a pale yellowish line margined with black, bounds the back part of the fore and hind legs; an irregular spot on the extremity of the rump; beneath, granulated on the abdomen, legs and thighs; a character also perceptible in some degree, on the upper surface. Head rather obtuse; 
lower lip whitish ; throat, clavicle, and auricles, minutely"spotted with black dots; irides golden copper. When resting on a dark substance, it changes at pleasure to a dark ashen hue, the lines becoming black and prominent, and the spots on the head and rump very perceptible, as also the transverse bars on the upper surface of the legs. Length of the body from the snout, to the vent, one inch; of hinder thighs and legs, each half an inch; of tarsus and toes, seven tenths of an inch; of the largest toe, four tenths of an inch. Whole length of the fore legs, half an inch."

\section{Hyla. Laurenti.}

Generic characters. Body in general elongated; upper jaw and palate furnished with teeth; tympanum apparent; no post tympanal glands; fingers long, and with the tocs terminating in rounded viscous pellets.

\section{H. versicolor. Le Conte. The common Tree Toad.}

Ann. Lyc. N. Y. vol. i. p. 281.

Harlan's Med. and Phys. Res. p. 109.

As the tree toad, this species is commonly known throughout New England, from the circumstance of its being more generally found upon trees than in any other situation; its color conceals it admirably, and it often elıdes a careful search on account of its similarity to the object upon which it may be resting. A specimen two inches in length, exhibits the following appearances. Above, of a light ash color, with a brownish cruciform marking between the shoulders, and smaller irregularly formed blotches distributed over various parts of the back; beneath, white, granulated, with a yellowish tint at the posterior portion of the sides. Head, broad; snout, blunt. Eyes, large; pupils, black; irides, golden. Extremities ash colored above. Anterior extremities with a small number of brown markings; beneath, white and brownish; four fingers free, terminating in pellets. Posterior extremities 
transversely barred; beneath, granulated, yellowish white, becoming yellow near the abdomen and upon the legs; five toes, terminating; like the fingers, in pellets.

An acrid secretion protects the skin of this species from its enemies. Its principal food is insects.

H. squirella. Bosc. 'The little peeping Hyla.

Ann. Lyc. N. Y. vol. i. p. 279.

Harlau's Med. and Plyys. Res. p. 107.

N. A. Herpet. vol i. p. 105.

The only specimen I have seen of this species was in a dried state; its colors were destroyed and its proportions much changed from life. I have therefore no hesitation in copying the description and observations of my friend, Dr. Holbrook, as published in the first volume of his "North American Herpetology:"

"Characters. Body olive green above, marked with dark brown blotches irregularly disposed ; a transverse dusky band between the orbits; whitish beneath and granulated; head short, with a white line extending along the upper lip to the shoulders.

Description. The head is short, with a dark band between the orbits, the line from each orbit being directed backwards so as to meet at an angle; the snout is obtuse, with an indistinct dark band extending from the nostrils to the eyes, below which is a white line along the margin of the upper lip, reaching to the shoulder; the lower jaw is almost white; the nostrils are placed near the extremity of the snout; the eyes are prominent; the pupils black; the irides golden; the tympanum is bronzed and surrounded by an indistinct circle of dark brown. The skin is smooth; the body short and depressed while living; the back is olive green, with irregular blotches of darker olive; the flanks are gray. The inferior surface of the body is granulated, greenish white in front, with a few dark spots at the throat; the posterior part of the abdo- 
men is darker. The anterior extremities are olive green above, with occasional spots of brown, and flesh colored beneath; the fingers are four in number, distinct, and each terminating in a viscous pellet. The posterior extremities are long, green above, obscurely blended with dark brown, and flesh colored beneath, tinged with yellow externally; the lower surface of the thigh is granulated; the toes are five in number, and semipalmated.

Dimensions. Length of the body and head, $11-4$ inches; of the thigh, 4-5ths of an inch; of the leg, 4-5ths of an inch; of the tarsus and toes, 9-10ths of an inch.

Geographical distribution. Its most northern limit must be considered as lat. $34^{\circ}$; we have no evidence of its being found farther north. It abounds in South Carolina, Georgia and Florida; how far west of these States it may exist cannot at present be determined.

Habits. This animal is found on trees, often seeking shelter under the bark of such as are decaying; it frequently chooses old logs for its place of hybernation. In fine weather and after showers, it climbs even the highest tices in search of insects.

General remarks. The colors of this animal are even more changeable than in any species with which I am acquainted. I have seen it pass in a few moments from a light green, unspotted and as intense as that of Hyla lateralis, to ash color, and to a dull brown with darker spots; the spots also at times taking on different tints from the general surface. The markings, too, vary exceedingly in different individuals, the white line on the upper lip and the band between the orbits alone presenting some constancy. Daudin remarks that the leg is "shorter than the thigh ;" we have found them nearly equal in length, and this character is by no means so conspicuous as in $H$. versicolor.

Daudin first described this animal, and gave a figure of it, from a drawing furnished him by Bosc. Leconte has given the latest and most detailed account of it, establishing three 
principal varieties, in one of which the spots, as well as the yellow on the thighs, disappear altogether."

The specimen I possess was captured in Roxbury.

\section{Buro. Laurenti.}

Generic characters. Head, short; jaws without teeth ; tympanum visible; bchind the ear is a large glandular tumour, having visible pores; body short, thick, swollen, covered with warts or papillae; posterior extremities but slightly elongated.

\section{B. Americanus. The common Toad.}

Harlan's Med. and Phys. Res. p. 109.

N. A. Herpetol. vol. i. p. 75.

This very common species is beginning to be looked upon by the horticulturalist in the light of a benefactor, and by many is carefully preserved on their grounds for the benefits it affords them by feeding upon noxious insects.

A fine specimen, three inches in length, furnishes the following description: Greatest width, two inches. Body, brownish, mottled with black blotches; its whole upper surface covered with prominent tubercles; those upon the back, larger; beneath, granulated, yellowish, sprinkled with black spots. Head large; superciliary ridges prominent; tympanum small, light colored, with an irregular darker colored black marking within its circumference. Mouth, large. Post tympanal glands large, equal in length to the distance between them. Eyes large; pupils black; irides beautifully reticulated with black and golden; eyelids tuberculated. Between the eyes, on the top of the head, a yellowish white line commences, which terminates at the posterior extremity of the body.

The extremities above, of the same color as the back; beneath, the color of the abdomen. A few small dark colored blotches upon the anterior extremities; larger spots, sometimes 
transverse, upon the posterior. Fingers four in number, short, free. Toes five in number, semipalmated; the second, much the longest; a large tubercle beneath, resembles somewhat a sixth toe.

\section{SALAMANDRA. Brogniart.}

Generic characters. Body elongated; tail long; extremities four; fingers four; toes five; no tympanum; numerous small teeth in the jaws and palate; tongue as in frogs; no sternum; ribs rudimental; pelvis suspended by ligaments.

S. erythronota. Green. The red-backed Salamander.

Journal Acad. Nat. Sciences, vol. i. p. 356.

Harlau's Med. and Phys. Res. p. 95.

N. A. Herpet. vol. iii. p. 113, et fig.

This beantiful and quite common species presents the following characters. My description is drawn up from a specimen between three and four inches in length. Tail rather shorter than the body, cylindrical, gradually tapering to a sharp point. On the upper part of the body, a broad band of a reddish brown color, sprinkled with brown spots, extending from the snout to the extremity of the tail, being less marked however upon the latter. Beneath, cinereous; much darker upon the sides. Throat whitish, having a distinct fold. Upper part of the head and tail, and also the sides of the body, presenting under the microscope, a beautiful metallic lustre. Head wider than the body, three lines in length, one and a half lines in width. Eyes very prominent; pupils black; irides metallic-colored. Anterior feet with four toes; posterior, five toed.

The motions of this species are very agile; walking rapidly when undisturbed, and running by sudden and irregular jerks when taken. I kept specimens alive several weeks by allowing them dead leaves, which were constantly kept moistened. From correspondents, I have received them from Cambridge, Roxbury, Milton and Amherst, at which places they were found under stones and decayed wood. 
S. symmetrica. Harlan. The symmetrical Salamander.

Journal Acad. Nat. Sciences, vol. v. p. 158.

N. A. Herpetol. vol. ii. p. 59, et fig.

'The fine specimens before me of this species, were found at Amherst, under decaying wood and leaves, by Professor Adams.

Length, three inches; tail, the length of the body, circular at the base, compressed towards the extremity. Whole upper part of the body, of a salmon brown color; on each side of the spine, from three to seven small ocellated spots of a beautiful vermillion color, surrounded by a black areola; skin above, covered with innumerable very minute tubercles, scarcely discernible without a glass, giving it a rough appearance. Beneath, of a golden orange color, sprinkled with minute black points, from the tip of the chin to the very extremity of the tail. Head three lines long, two wide, flattened; two longitudinal very obvious ridges, the length of the head, between the eyes. Eyes, not very prominent, of a deep black color, with a bright golden iris. Snout, obtuse. Anterior feet, with four toes; posterior, five toed.

In young specimens, the whole back is covered with minute black dots, and the sides have fewer ocellated spots than in the adult. The largest specimen in my possession, has seven ocellated spots on each side; in different specimens, these spots vary in number; but in all the specimens I have seen, an equal number exists on each side of the spine, in the same specimen.

The motions of this species are much less rapid than those of the "erythronota." It casts its skin in June. In the stomach of this species are found spiders, and detached portions of insects.

Dr. Holbrook has received this species from Florida; and $\mathbf{J}$. W. Randall, M. D. of this city, brought me specimens from Hallowell, Maine. 
S. fasciata. Green. The banded Salamander.

Journal Academy Nat. Sciences, vol. i. p. 350.

Harlan's Med. and Phys. Res. p. 94.

N. A. Herpet. vol. iii. p. 103, et fig.

The beautiful living specimen, from which my description is made, was found by Professor Hitchcock, at Monson, and kindly transmitted to me.

Its length is five inches; length of the tail equal to that of the body; oval at its anterior portion, slightly compressed in its middle, and pointed at its posterior extremity. Upper part of the body, of a light clay or ash color, with transverse dark brown bands extending from the head to the extremity of the tail. Whole under portion of the body, of a dark slate color.

Width of the head, equal to one half its length. Eyes prominent; pupils, black; irides, color of the abdomen. Snout, rounded. Anterior feet, four toed; posterior, five toed.

Some of the bands in my specimen are confluent.

This is the only individual $\mathbf{I}$ have seen, and therefore think it must be a rare species with us.

S. venenosa. Barton. The violet-colored Salamander.

Daud. Hist. Nat. des Rept. t. viii. p. 229.

Trans. of Amer. Phil. Soc. vol. vi. et fig.

Harlan's Med. and Phys. Res. p. 93.

N. A. Herpetol. vol. iii: p. 105, et fig.

Dr. Barton's account of this, our earliest described Salamander, which is exceedingly interesting, is contained in the "Transactions of the American Philosophical Society." His specimen. was six inches and eight tenths of an inch in length. It grows to a larger size even than this.

The specimen upon my table, is five inches in length; tail, two and a half inches long, cylindrical at the base, compressed towards the extremity. All the upper part of the body, of a dark 
purple color. On each side of the dorsal line, a longitudinal row of oval, circular and oblong spots of a bright yellow color, varying in size; these spots commence on the back part of the head, and are continued towards the extremity of the tail, where they become single. Smaller spots of the same color on the legs and feet, and above one of the eycs. Beneath, the body is of a lighter color, with a great number of very minute white dots. Length of the head, two thirds of an inch; width across, half an inch. Eyes, of a deep black color, and very prominent. A strongly marked cuticular fold around the throat.

The above described specimen was found in Roxbury.

In another individual, found by Professor $\Lambda$ dams, at New Bedford, three inches in length, a row of small yellow spots, resembling a broken line, partially encircles the eyes; in this specimen, the abdomen is destitute of the small white points so perceptible in the preceding specimen, but its sides are covered with them.

A specimen of this species was brought me from Kennebec county, Maine, by J. W. Randall, M. D.

S. salmonea. Nobis. The salmon-colored Salamander.

N. A. Herpetol. vol. iii. p. 101, et fig.

The specimen described by me in Holbrook's "American Herpetology," was found by Dr. Binney, in Vermont : but as Dr. Holbrook says an individual of this species has been "found in the neighborhood of Danvers, Massachusetts," I can have no hesitation in admitting it in this report.

Length, six and a half inches; length of the tail, two and a half inches; compressed, carinated above, gradually tapering to a point. Whole uprer part of the body, head, tail and legs, of a yellowish brown color; the sides of the head, neck, body, tail and legs, of a salmon color. The entire surface of all the upper portion, as well as sides, spotted with irregular grayish 
markings, which are more obvious on the lighter colored sides. Beneath, the head and body white; light salmon color beneath tlie tail.

Head, one inch in length; width of the head, back of the eyes, four lines; snout, very obtuse ; nostrils, rather small; a strongly marked cuticular fold upon the neck. Eyes, remote, and very prominent; pupils, deep black, with a metallic, copper-colored iris; from the edge of the upper lip, just exterior to the nostrils, arises a salmon-colored line about a fourth of a line in width, which runs back to the inner angle of the eye, and passing up over the eye loses itself upon the middle of the back part.

This species was found upon moist land. It lived a year in confinement, and appeared perfectly healthy, eating voraciously of flies.

S. dorsalis. Harlan. The many spotted Salamander.

Journal Academy Nat. Sciences, vol, vi. p. 101.

Harl. Med. and Phys. Res. p. 99.

N. A. Herpet. v. ii. p. 57, et fig.

From Roxbury and Amherst I have received numerous specimens of this species by the aid of Professor Adams, and my brother-in-law Dr. Brewer. An individual three inches and three lines in length, exhibits the following characters. Tail rather longer than the body. Body, above, dark olive, and granulated as. in the "symmetrica;" lighter on the sides. All the upper part of the body, together with the feet, to the extremities of the toes and tail, sprinkled with innumerable black points. Beneath the body, the legs, and tail, of a sulphur color, darker under the tail, and tinged with olive; similar black points with those above, are spread over the surface beneath, which in some specimens are much larger than in the "symmetrica." Eyes prominent; pupils and irides similar to those of the "symmetrica." Tail very much compressed in its whole length, carinated above and beneath. Vent very promincilt. Anterior 
feet with four toes; posterior five toed. Ocellated spots of a similar color with those on the "symmetrica," but smaller, are arranged on each side of the spine; these spots vary in number on the two sides; thus, of the eight living specimens before me, of nearly the same size, but three have five of these spots on each sicie; the others have three and four and six and seven on one side, with five on the other; and one specimen has nine on one side, eleven on the other, with a single line with one similar spot beneath this line on the side, and still another beneath, on the edge of the yellow abdomen.

All the specimens I have seen were taken in broolis. In the stomachs of several individuals, were found fragments of the genera "Lymnea," and "Physa." I have kept these animals for months, they seeming to thrive very well by a daily supply of fresh water, and a sufficient quantity of flies which they seize by a sudden spring, and swallow by several continued efforts. This species casts its exuvia in June, and the new cuticle is in all respeets similar to the former.

In the "Journal of the Academy of Natural Sciences," Harlan describes a salamander which he calls "dorsalis," some of the specific characters of which, are "a whitish dorsal line extending from the occiput over the tail; a row of whitish colored oblons spots on each side of the dorsal line; beneath, freckled with blaek dots."

Not meeting with any description which agreed with the species I have just described, two years since I read an account of it before the Boston Society of Natural History, under the name of "S. millepunctuta." My friend, Dr. Holbrook, while examining, with me, the last season, the reptiles belonging to the above mentioned Society, assured me he had seen the specimen in Philadelphia originally described by Harlan, and that it was the same species that I had supposed new. How Harlan could have made such a description as he has from this species, it is difficult to imagine. He must have described a specimen preserved in spirits, else he could not have seen "a row of whitish colored oblong spots on each side of the dorsal line ;" but even alcohol could not produce "a whitish 
dorsal line," where no defined line existed, of any color, in life. Dr. Holbrook's second volume of his "North American Herpetology," containing a description of the "S. dorsalis," has, within a few months, issued from the press. Was I governed by his description, which makes no mention of the innumerable black dots above, which cover its entire upper as well as under surface in every individual of whatever age I have. met with; or his plate, which corresponds with it, I might be induced to disbelieve the identity of our species; but preferring to think the omission may have been accidental, I would yicld my doubts to the conviction of that distinguished herpetologist.

S. picta. Harlan. The painted Salamander.

Journal Academy Nat. Sciences, vol. v. p. 136.

Harlan's Med. and Phys. Res. p. 98.

I have never met with this species; but Dr. Pickering, of Philadelphia, informed me, some time since, that a specimen belonged to the cabinet of the "Academy of Natural Sciences," which was found in a well at Ipswich in this State; I therefore extract from the Journal of the Academy, Harlan's description of the species :

"Body blackish or dark slate color above, yellowish or light orange color beneath; skin beneath the neck, folded; head large; legs strong; tail compressed at its inferior portion nearly the length of the body.

Dimensions. Total length nearly four inches; body rather more than two inches; tail less than two inches; leneth of the head six tenths; breadth five tenths; length of the lind legs six tenths; of the fore legs four tenths.

Description. Head large, rather flat; occiput broad, slightly protuberant; snout obtuse, rounded anteriorly; rictus of the mouth wide, extending posteriorly to the eyes; anterior borders of the lips slightly undulating; skin of the throat folded, so as to form a collar nearly surrounding the neck; body above, blackish; a longitudiral furrow extending from the 
occiput along the back to the base of the tail ; inferior portion of the body obsoletely punctured with dark spots, more visible on the sides; legs short, strong, and thick, externally of the color of the back; internally of the color of the belly; tail subquadrangular for the first two thirds; the remainder or inferior portion abruptly compressed, pointed, with the superior and inferior borders carinate."

S. glutinosa. Green. The blue spotted Salamander.

Journal Academy Nat. Sciences, vol. i. p. 357.

Harlan's Med. and Phys. Res. p. 94.

The only specimen I have seen, was sent me from Andover by Mr. Alonzo Gray. It continued alive for several weeks, and presented the following characters:

Length, six inches. Whole upper part of the body, of a very dark brown thickly sprinkled with distinct light blue spots. Sides appearing quite light colored from the blue spots having become confluent. Abdomen lighter colored than the back, exhibiting the spots more numerous and distinct than the back. Head, three quarters of an inch long; nearly half an inch wide, flattened above. Eyes very prominent; of a deep black color, widely separated from each other. Nostrils rather small. Legs, color of the body, and spotted like it. Anterior feet, four toed; posterior, five toed, and unusually long. 'Tail, length of the body; much compressed throughout its whole extent, save the extremities, the anterior of which is circular, the posterior pointed.

S. maculata. Green. The brown spotted Salamander.

Journal Academy Nat. Sciences, vol. i. p. 350.

Harlan's Mled. and Phys. Res. p. 96.

The only specimen of this species I have seen was brought me by John W. Randall, M. D., of this city, who found it in a pond in Groton. This is quite a young specimen, being 
only an inch and a half long, and having the branchiæ still attached; and as its colors have somewhat changed in the alcohol, I extract Green's description from the Journal of the Philadelphia Academy. "Length, four or five inches; tail about as long as the body, tapering, slightly compressed, and pointed; snout rounded; back whitish, sprinkled with irregular, reddish brown spots; beneath white; anterior feet, four toed, posterior feet five toed.

Nоте. Individuals of this species vary much in size, and in the number of spots. I have one about three inches long, with the tail more compressed and obtuse, than the above."

All the Salamanders here described, feed upon insects, which they devour in very large numbers, and hence their utility cannot be questioned. 


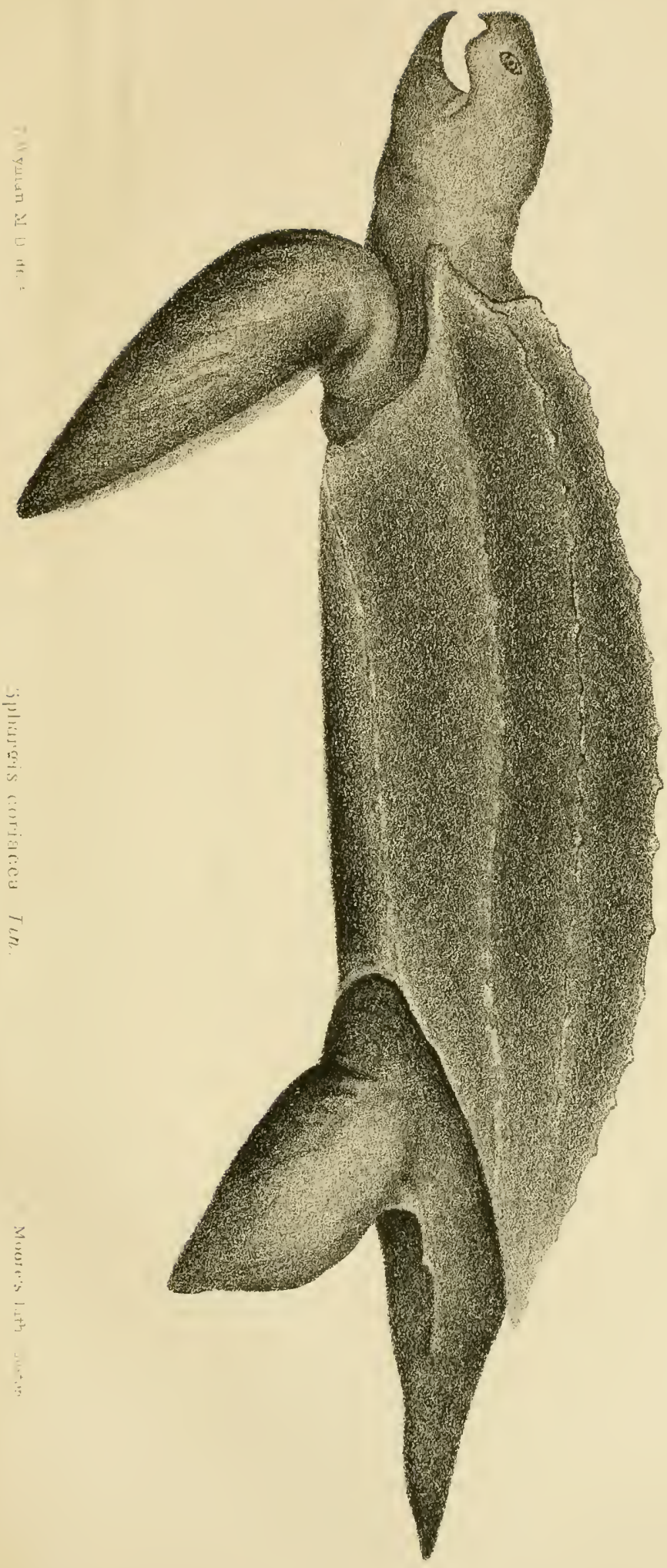



. 








1

$x^{2}+x^{2}$

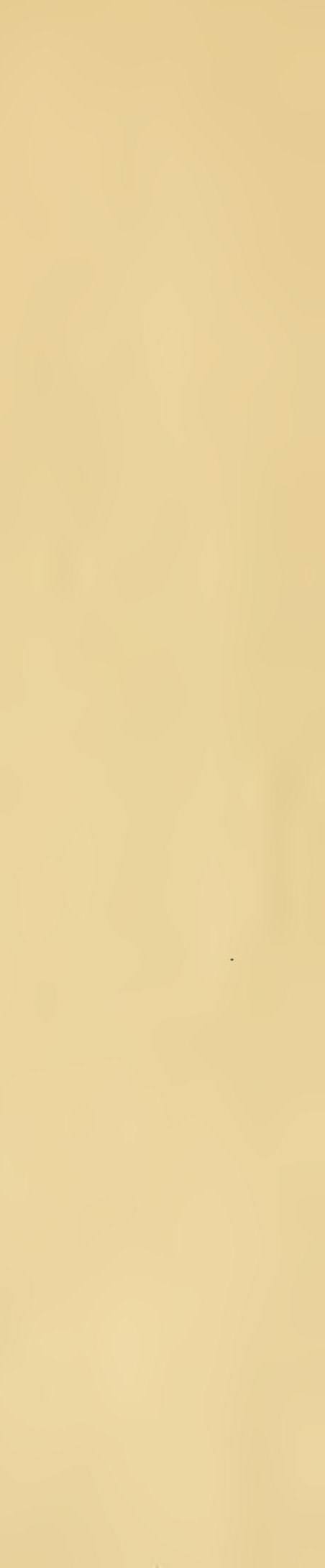


